\title{
Kontestasi Aktor dalam Proses Revisi Rencana Tata Ruang Provinsi (RTRWP) di Indonesia (Studi Kasus: Revisi RTRW Provinsi Riau)
}

\section{S. Suprapto ${ }^{1}$}

Fakultas Kehutanan, Universitas Gadjah Mada, Yogyakarta, Indonesia

\section{San Afri Awang}

Fakultas Kehutanan, Universitas Gadjah Mada, Yogyakarta, Indonesia

\author{
Ahmad Maryudi \\ Fakultas Kehutanan, Universitas Gadjah Mada, Yogyakarta, Indonesia
}

\section{Wahyu Wardhana}

Fakultas Kehutanan, Universitas Gadjah Mada, Yogyakarta, Indonesia

Artikel Masuk : 2 Agustus 2018

Artikel Diterima : 17 Oktober 2018

Tersedia Online : 31 Desember 2018

\begin{abstract}
Abstrak: Provinsi Riau merupakan salah satu provinsi yang belum menyelesaikan RTRWP sampai dengan tahun 2017. Salah satu hal yang menjadi penyebabnya terkait dengan konflik antaraktor yang terlibat di dalamnya. Masing-masing aktor menggunakan pengaruh kekuasaan yang dimiliki untuk mempertahankan kepentingannya. Penelitian ini bertujuan untuk mengidentifikasi, mengukur pengaruh aktor serta mendapatkan rekomendasi dalam menyelesaikan persoalan revisi RTRWP Riau. Metode yang digunakan dalam penelitian ini adalah pendekatan Actor-Centered Power (ACP) yang didukung dengan Content Analysis terhadap dokumen RTRWP Riau dan peraturan perundangan yang terkait. Hasil temuan penelitian menunjukkan bahwa setidaknya terdapat sembilan aktor yang terlibat dalam proses revisi RTRWP Riau, dengan peran Kementerian Lingkungan Hidup dan Kehutanan (LHK) menjadi yang paling kuat disusul oleh peran Pemerintah Daerah Provinsi Riau. Penelitian juga menunjukkan munculnya peran Ombudsman, swasta (perusahaan), dan lembaga swadaya masyarakat (LSM) dalam kontestasi revisi RTRWP Riau. Dalam proses percepatan penyelesaian Rancangan Peraturan Daerah (Ranperda) RTRWP Riau, diperlukan koordinasi dan integrasi antaraktor yang terlibat, penegakan hukum terhadap pelanggaran hukum yang terjadi serta pengelolaan konflik yang menyeluruh.
\end{abstract}

Kata Kunci: kontestasi aktor; pemerintah dan non-state actor, revisi RTRWP

Abstract: Riau Province is one of the provinces which have not revised the RTRWP until 2017. One possible cause relates to the conflicts of interest among the participating actors. Each actor exercises the power influences to secure individual interests. This study aims to identify the participating actors, to measure the power influences exchanged between the

\footnotetext{
${ }^{1}$ Korespondensi Penulis: Fakultas Kehutanan, Universitas Gadjah Mada, Yogyakarta, Indonesia email: prapto.jogja@gmail.com
} 


\section{Kontestasi Aktor dalam Proses Revisi Rencana Tata Ruang Provinsi (RTRWP) di Indonesia...}

actors and to recommend solutions for resolving the Riau's RTRWP revision issue. The method used is Actor-Centered Power (ACP) approach, which is supported by Content Analysis of Riau's RTRWP document and related regulations. The research findings show that there are at least nine actors involved in the revision process of the Riau's RTRWP, where the role of the Ministry of Environment and Forestry is the most powerful then followed by the Riau Province Government. The research also shows the involvement of Ombudsman Agency, private corporations, and non-governmental organization (NGO) in the Riau's RTRWP revision process. To accelerate the completion of the Riau's RTRWP Regional Regulation Draft, coordination and integration between the participating actors are required as well as the law enforcement against legal violations and comprehensive conflict management.

Keywords: actor contestation; state and non-state actor; RTRWP revision

\section{Pendahuluan}

Perubahan tata guna dan alokasi lahan di Indonesia secara umum dipengaruhi oleh perubahan struktur pemerintahan yang ada pada saat itu (McCarthy, 2000), yang melibatkan pertarungan antara kementerian dan instansi-instansi lainnya baik di dalam pemerintah pusat maupun pemerintah daerah (Maryudi, 2015). Berdasarkan UndangUndang (UU) Nomor 24 Tahun 1992 tentang Penataan Ruang yang kemudian diperbarui dengan UU Nomor 26 Tahun 2007, maka seluruh provinsi diwajibkan untuk menyusun Rencana Tata Ruang Wilayah Provinsi (RTRWP) yang berfungsi untuk mengatur pengelolaan kawasan lindung dan kawasan budidaya yang diatur dalam Peraturan Daerah (Perda) masing-masing (Santoso, 2003) dan di bawah otoritas Badan Perencanaan Pembangunan Nasional (Bappenas) yang berkoordinasi dengan Badan Perencanaan Pembangunan Daerah (Bappeda) (Brockhaus et al., 2012).

Provinsi Riau merupakan salah satu dari empat provinsi yang belum menyelesaikan rencana tata ruang sampai dengan tahun 2017 dan baru mendapatkan persetujuan substansi (Kementerian ATR/BPN, 2016). Permasalahan ini muncul diduga akibat tidak terselesaikannya proses paduserasi antara Tata Guna Hutan Kesepakatan (TGHK) dan RTRWP Riau pada tahun 1999 (Kartodiharjo, 2010), sehingga menghambat agenda pembangunan daerah (Wibowo \& Giessen, 2015). Melalui UU Nomor 26 Tahun 2007, telah ditegaskan bahwa seluruh RTRWP seharusnya sudah dapat diselesaikan pada tahun 2009 (dua tahun semenjak diundangkan), sedangkan Rencana Tata Ruang Wilayah Kabupaten (RTRWK) harus sudah dapat diselesaikan tiga tahun semenjak diundangkan yaitu pada tahun 2010 (Kartodiharjo, 2010).

Persoalan lain yang mengakibatkan tersendatnya proses tata ruang adalah adanya konflik kepentingan antara pemerintah pusat, pemerintah provinsi dan pemerintah kabupaten/kota (Colfer et al., 2009; Kartodiharjo, 2010). Hal ini menandakan bahwa pemerintah daerah lebih inferior daripada pemerintah pusat terutama terkait dengan kapasitas pembuatan undang-undang (Hudalah \& Woltjer, 2007). Kepentingan dalam proses tata ruang juga melibatkan pihak swasta (Myers \& Ardiansyah, 2014). Pernyataan Ketua Jurusan Planologi Universitas Islam Riau dalam Riau Pos (2014) menyebutkan bahwa belum ditandatanganinya RTRWP, diduga ada kepentingan korporasi di balik semua itu (Riau Pos, 2014). Hal ini membuktikan bahwa persoalan tata ruang di Indonesia sangat kompleks (Brockhaus et al., 2012), dan secara umum dipengaruhi oleh faktor internal yaitu kekuatan institusi, budaya politik dan pengaruh eksternal yaitu perkembangan gagasan neoliberalisme global (Hudalah \& Woltjer, 2007).

Sektor kehutanan yang dahulu menjadi primadona terus mengalami penurunan peran dalam pembangunan (Susanti \& Maryudi, 2016), sehingga memunculkan alternatif penggunaan kawasan hutan untuk tujuan pembangunan di luar kehutanan (Krott, 2005). 
Konflik penggunaan kawasan hutan tersebut muncul terkait siapa, bagaimana dan untuk siapa lahan tersebut diperuntukkan (FAO, 2010), dengan kondisi sumber daya hutan yang berada dalam kondisi yang langka (Hubo \& Krott, 2013). Salah satu konflik yang terjadi adalah alokasi dan penggunaan kawasan hutan untuk sektor perkebunan. Casson (2000) mencatat bahwa antara tahun 1982 dan 1999 telah terjadi konversi perkebunan kelapa sawit seluas enam juta hektar, yang berasal dari kawasan hutan (Casson et al., 2007). Tingginya minat terhadap perkebunan kelapa sawit terkait erat dengan kepentingan pemerintah daerah dalam mencukupi kepentingan ekonomi (Prabowo et al., 2017).

Kompetisi antaraktor menjadi faktor penting dalam penggunaan lahan dan politik kehutanan. Masing-masing pihak akan membawa kepentingannya, yang akan mereka gunakan sebagai orientasi dalam melakukan kegiatan untuk memperoleh manfaat dari kegiatan tersebut (Krott et al., 2014). Tidak terkecuali dengan aktor birokrasi pemerintah yang akan mempertahankan kepentingan mereka untuk mendapatkan alokasi anggaran, menegaskan kewenangan, serta mewujudkan mandat resmi dan tanggung jawab politik yang ada pada mereka (Krott et al., 2014; Niskanen, 1971; Peters, 2001).

Dalam pengelolaan hutan sering dijumpai bahwa kelompok yang kuat akan mampu menentukan kebijakan yang dikeluarkan (McCarthy, 2000) dan berusaha untuk memformulasikan program-program politik di bidang kehutanan (Aurenhammer, 2013). $\mathrm{Hal}$ ini tidak terlepas dari kawasan hutan negara di Indonesia yang banyak dipengaruhi oleh kepentingan para pelaku ekonomi (Maryudi, 2015). Beberapa penelitian terkait alokasi penggunaan lahan dalam tata ruang provinsi menemukan fakta bahwa terdapat permasalahan dalam usulan revisi RTRWP terkait dengan mekanisme perubahan kawasan hutan (Syahadat \& Subarudi, 2012), adanya ketidaksinkronan antara RTRWP dan TGHK yang sudah ada sebelumnya (Santoso, 2003), serta adanya perbedaan pedoman yang akan digunakan sebagai acuan dalam penentuan RTRWP antara daerah dan pusat (Setiawan et al., 2017). Berdasarkan beberapa permasalahan tersebut, dapat dirumuskan bahwa konflik dalam proses alokasi lahan dalam revisi RTRWP disebabkan adanya kontestasi aktor dengan berbagai kepentingan yang mereka punya. Dalam tulisan ini persoalan kontestasi aktor tersebut akan digambarkan melalui pendekatan Actor-Centered Power (ACP) yang dikembangkan (Krott et al., 2014). Melalui pendekatan ini diharapkan keterlibatan aktor dengan pengaruh yang mereka miliki dalam proses alokasi penggunaan lahan RTRWP di Provinsi Riau akan terlihat. Adapun tujuan penelitian dilakukan yaitu untuk: 1) mengidentifikasi aktor yang terlibat dalam proses revisi RTRW Provinsi Riau, 2) menganalisis pengaruh kekuasaan dari kontestasi kepentingan aktor antara lain antara birokrasi yang ada pada sektor-sektor yang berbasis lahan dalam penggunaan lahan kehutanan, masyarakat dan swasta yang dimanifestasikan dalam perebutan alokasi ruang dalam RTRW Provinsi Riau 2017-2035, dan 3) merekomendasikan rencana penyelesaian persoalan kontestasi ini.

Penelitian ini menjadi penting dilakukan sebagai upaya untuk mencari dan mengurai benang merah berlarut-larutnya proses penetapan RTRWP Riau hingga saat ini, agar penyusunan RTRWP Riau segera selesai. Secara hukum RTRWP merupakan dasar hukum yang kuat bagi daerah untuk mengelola wilayah yang menjadi kewenangan mereka (Wibowo \& Giessen, 2015), sehingga pemerintah daerah berusaha mempercepat proses penyelesaiannya. Dengan berlarutnya penyelesaian revisi RTRWP ini dikhawatirkan akan menghambat investasi di Riau dan rawan terjadi pelanggaran hukum di dalamnya.

\section{Metode Penelitian}

Penelitian ini menggunakan pendekatan kualitatif untuk menjelaskan permasalahan dalam penelitian. Sugiyono (2016) menyatakan bahwa metode ini disebut juga metode interpretatif karena berkenaan dengan interpretasi terhadap data yang ditemukan di lapangan. Dalam melakukan identifikasi aktor dan melakukan observasi terhadap pengaruh 
setiap aktor, penelitian ini menggunakan pendekatan Actor-Centered Power (ACP) yang terdiri dari tiga elemen kekuasaan yaitu koersi, disinsentif dan informasi dominan (Krott et al., 2014) sebagaimana dijelaskan pada Tabel 1. Pendekatan ACP fokus pada pengaruh setiap aktor dan potensi penggunaan pengaruh tersebut untuk menciptakan, menjalankan bahkan melakukan pemblokiran terhadap agenda yang mereka lakukan sendiri atau aktor lain (Wibowo \& Giessen, 2015). Penilaian pengaruh dilakukan melalui survei awal kuantitatif, diikuti survei kualitatif, dan diakhiri dengan data triangulasi (Schusser, Krott, Devkota, \& Maryudi, 2013).

Tabel 1. Elemen Kekuasaan, Fakta Lapangan dan Contoh Tindakan

\begin{tabular}{|c|c|c|c|}
\hline Elemen & Definisi & Fakta Yang Tampak & Contoh \\
\hline Koersi & $\begin{array}{l}\text { Mengubah perilaku } \\
\text { subordinat dengan } \\
\text { paksaan }\end{array}$ & $\begin{array}{l}\text { Tindakan fisik, ancaman } \\
\text { untuk melakukan } \\
\text { tindakan kekerasan atau } \\
\text { sumber untuk tindakan } \\
\text { kekerasan }\end{array}$ & $\begin{array}{l}\text { Regulasi perizinan dan } \\
\text { sanksi untuk pelanggaran }\end{array}$ \\
\hline Disinsentif & $\begin{array}{l}\text { Mengubah perilaku } \\
\text { subordinat melalui } \\
\text { pemberian keuntungan } \\
\text { atau kerugian } \\
\text { (dis)advantages }\end{array}$ & $\begin{array}{l}\text { Pemberian atau } \\
\text { mengancam dengan } \\
\text { pencabutan sumber } \\
\text { keuntungan materiil atau } \\
\text { nonmateriil }\end{array}$ & $\begin{array}{l}\text { Dukungan finansial dan } \\
\text { pencabutan subsidi }\end{array}$ \\
\hline $\begin{array}{l}\text { Informasi } \\
\text { dominan }\end{array}$ & $\begin{array}{l}\text { Mengubah perilaku } \\
\text { subordinat melalui } \\
\text { informasi yang tidak } \\
\text { terverifikasi }\end{array}$ & $\begin{array}{l}\text { Memberikan atau } \\
\text { mengancam dengan } \\
\text { mencabut sumber } \\
\text { informasi yang tidak } \\
\text { terverifikasi }\end{array}$ & $\begin{array}{l}\text { Kemampuan para ahli } \\
\text { dalam mengelola hutan }\end{array}$ \\
\hline
\end{tabular}

Metode pengambilan data dilakukan dengan mengumpulkan data primer dan data sekunder. Data primer diperoleh melalui wawancara tatap muka dengan informan kunci untuk melihat penggunaan sumber kekuasaan yang mereka miliki. Metode ini merupakan salah satu teknik yang paling sering digunakan dalam penelitian kualitatif (Opdenakker, 2006) untuk mendapatkan konstruksi makna dalam suatu topik tertentu (Esterberg, 2002). Lebih lanjut Esterberg (2002) menuliskan bahwa salah satu teknik wawancara adalah wawancara semi-terstruktur atau in-depth interview. Wawancara semi-terstruktur dilakukan dengan pertimbangan lebih cocok untuk mengeksplorasi persepsi dan opini responden/aktor (Esterberg, 2002; Louise Barriball \& While, 1994). Wawancara semiterstruktur dilakukan terhadap para pengambil kebijakan atau aktor yang terkait dengan proses tata ruang di Riau dengan dipandu dengan daftar pertanyaan yang telah ditetapkan sebelumnya (Longhurst, 2003). Kegiatan ini memungkinkan kelonggaran dalam merancang dan menyempurnakan panduan wawancara (Horton, Macve, \& Struyven, 2004). Kemudian, untuk keperluan analisis kuantitatif, maka jawaban dari hasil wawancara akan diberikan skor.

Aktor atau pemangku kepentingan yang terlibat dalam proses tata ruang di Provinsi Riau, dapat dikelompokkan menjadi aktor pemerintah dan nonpemerintah (Non State Actor/NSA). NSA adalah semua entitas yang bukan merupakan representasi pemerintah (Clapham, 2016). Merujuk istilah pemangku kepentingan yang mengacu pada pengguna sumber daya, pembentuk kebijakan dan penyedia layanan, maka beberapa aktor yang terlibat dalam proses revisi RTRWP Riau dapat dilihat pada Tabel 2.

Tabel 2. Daftar Wawancara dan Waktu Wawancara

\begin{tabular}{clc}
\hline No & Informan & Waktu \\
\hline 1 & Pegawai BPN Provinsi Riau & 23 Agustus 2017 \\
\hline
\end{tabular}




\begin{tabular}{clc}
\hline No & Informan & Waktu \\
\hline 2 & Anggota Tim Terpadu (Timdu) Review RTRWP Riau & 28 Agustus 2017 \\
3 & (Jaringan Kerja Penyelamat Hutan Riau) Jikalahari & 30 Agustus 2017 \\
4 & Kabid Dinas Lingkungan Hidup dan Kehutanan Riau & 10 Oktober 2017 \\
5 & Pegawai Dinas Perkebunan Riau & 27 Oktober 2017 \\
6 & Koalisi Rakyat Riau (KRR) & 29 Oktober 2017 \\
\hline
\end{tabular}

Data sekunder diperoleh melalui telaah isi atau content analysis. Analisis isi merupakan sebuah metode penelitian yang digunakan untuk menginterpretasikan makna dalam data tulisan (Hsieh \& Shannon, 2005) sehingga akan didapatkan kesimpulan yang valid (Krippendorff, 1989). Sebagai unit analisis adalah data teks dari dokumen terkait RTRW Provinsi Riau, dokumen pendukung lainnya, peraturan perundangan serta hasil penelitian lain yang termuat dalam tesis, disertasi dan jurnal. Data sekunder diperlukan untuk melengkapi hasil data survei kualitatif. Kemudian dilakukan analisis komparatif (triangulasi) untuk memvalidasi data yang sudah ada.

\section{Hasil dan Pembahasan}

\section{Tata Ruang Kehutanan Riau dari Waktu ke Waktu}

Dalam proses memperoleh persetujuan substansi kehutanan sebagaimana dilakukan dalam rangka penetapan RTRWP, sinkronisasi antara peta kawasan hutan dan perda RTRWP terdahulu sangat penting. Apalagi untuk Provinsi Riau, yang pada awalnya seluruh wilayahnya $100 \%$ merupakan kawasan hutan yang telah ditetapkan oleh pemerintah pusat melaui TGHK (Barr et al., 2006; Brockhaus et al., 2012).

Provinsi Riau pertama kali menggunakan acuan alokasi penataan ruang dengan menggunakan peta TGHK berdasarkan Surat Keputusan (SK) Menteri Kehutanan (Menhut) Nomor 173/Kpts-II/1986. TGHK secara formal ditujukan untuk mengatasi dan mengendalikan permasalahan perencanaan lintas sektor serta memfasilitasi pengembangan industri kehutanan, misalnya untuk pengembangan Hak Pengusahaan Hutan, Hutan Tanaman Industri dan perkebunan (Kartodihardjo \& Supriono, 2000; McCarthy, 2000), dan digunakan sebagai dasar alokasi lahan kehutanan. Selama ini peta TGHK tidak dapat digunakan dengan baik disebabkan beberapa hal antara lain:

1) Banyak mengabaikan kepentingan masyarakat akibat pembentukannya bersifat konsensus dan disusun secara top down. Hal ini karena dipengaruhi oleh sistem politik di Indonesia yang memang didesain untuk menciptakan kesepakatan melalui penerimaan hasil dari konsensus (Robertson-Snape, 1999). Dampaknya adalah banyak menimbulkan konflik di kemudian hari (Contreras-Hermosilla \& Fay, 2006; Kartodihardjo \& Supriono, 2000; Resosudarmo et al., 2012);

2) Memiliki keterbatasan akibat informasi tutupan vegetasi hutan dan karakteristik fisik dari lahan yang kurang akurat serta tingkat subjektivitas yang tinggi (Sève, 1999), batas TGHK yang tidak konsisten, tidak akurat (Clunie \& Applegate, 1994) dan masih bersifat sangat kasar (Lynch, 1999);

3) Secara teknik masih menggunakan skala peta yang sangat kecil (biasanya 1: 500.000), bukan data terbaru, sehingga akan mempersulit ketika akan ditransfer menjadi skala yang lebih besar (Sève, 1999);

4) Kontrol negara melalui Kementerian Kehutanan (Kemenhut) masih dominan ditunjukkan dengan proporsi kawasan hutan yang mencapai angka 76\% sedangkan 24\% sisanya di bawah kewenangan Badan Pertanahan Nasional (BPN) (ContrerasHermosilla \& Fay, 2006). Pada kasus proporsi kawasan hutan di Riau, 100\% kawasan yang ada berdasarkan TGHK merupakan kawasan hutan.

Berdasarkan UU Nomor 24 Tahun 1992 tentang Penataan Ruang, seluruh provinsi pada tahun 1992 diwajibkan mempersiapkan RTRWP yang diatur dalam Perda masing- 
masing (Santoso, 2003), di bawah otoritas Bappenas yang berkoordinasi dengan Bappeda (Brockhaus et al., 2012) serta harus dilakukan dengan melibatkan masyarakat dan lintas sektor di dalamnya (Sève, 1999). Pada periode 1992-1994, Provinsi Riau berhasil menerbitkan Perda Nomor 10 Tahun 1994 meskipun proses paduserasi belum selesai.

Perda ini tidak diakui oleh Kemenhut karena adanya ketidaksesuaian pola ruang kawasan hutan antara keduanya (Sinabutar, 2015; Tim Terpadu, 2012). Perbedaan nyata terlihat pada alokasi lahan yang akan digunakan untuk kawasan nonkehutanan. Akhirnya Kemenhut mengembalikan mandat alokasi lahan kehutanan mengikuti peta TGHK berdasarkan Surat Edaran (SE) Nomor 404/Menhut-II/2003 tanggal 10 Juli 2003 (Sinabutar, 2015). Salah satu isi SE tersebut adalah "bagi setiap provinsi yang belum ada Keputusan Menteri Kehutanan tentang penunjukan kembali atas kawasan hutan yang didasarkan pada hasil pemaduserasian antara RTRWP dengan TGHK, maka kawasan hutan pada provinsi tersebut mengacu dan berpedoman pada Keputusan Menteri Kehutanan tentang TGHK”.

Pada tahun 2009 setelah terbitnya UU Nomor 26 Tahun 2007, Gubernur Riau mengajukan usulan perubahan kawasan hutan diikuti beberapa kali revisi sampai dengan tahun 2012. Hal ini dilakukan dalam rangka review RTRWP sebagaimana amanat UU tersebut. Semestinya dengan UU ini, pemerintah provinsi memiliki kewenangan yang lebih luas dalam perencanaan tata ruang mereka bahkan dapat menetapkan komponen yang belum diatur dalam aturan yang lebih tinggi (Rukmana, 2015).

Selama kurun waktu tahun 1986 sampai dengan 2016, kawasan hutan di Provinsi Riau telah mengalami transformasi dari kawasan hutan menjadi areal penggunaan lain (APL). Gambar 3 menunjukkan bahwa terjadinya perubahan terbesar dalam proporsi kawasan hutan di Provinsi Riau terutama pada Kawasan Hutan Produksi yang dapat dikonversi (HPK) menjadi APL. Hal ini disebabkan bahwa sejak awal kawasan hutan yang berfungsi sebagai HPK ditujukan untuk mengakomodasi dinamika pembangunan yang berlangsung (Tim Terpadu, 2012). Perubahan yang dimaksud adalah untuk kegiatan pembangunan nonkehutanan seperti perkebunan, pertanian, transmigrasi, dan lain-lain.

Perbedaan jelas hasil transformasi kawasan hutan dapat dilihat dari perubahan penutupan lahan yang ada di Provinsi Riau tahun 1990-2015 (Gambar 4). Tutupan lahan yang masih berhutan semakin menurun dari tahun ke tahun, begitu juga sebaliknya dengan tutupan lahan nonhutan yang semakin bertambah luasannya. Hal ini mengindikasikan bahwa proses dan kebijakan alokasi lahan di Indonesia banyak didominasi oleh paradigma pembangunan yang fokus pada pembangunan ekonomi skala besar (Brockhaus et al., 2012; Maryudi, 2015).

Pernyataan ini diperkuat hasil pengolahan data yang ada, bahwa banyak perizinan berbasis lahan di Riau tidak sesuai peruntukannya. Apabila ditumpangsusunkan dengan Peraturan Daerah No. 10/1994 tentang RTRWP Riau diketahui bahwa terdapat 29,6\% Izin Usaha Pemanfaatan Hasil Hutan Kayu-Hutan Tanaman Industri (IUPHHK-HTI) berada di kawasan lindung dan areal peruntukan khusus perkebunan. Untuk izin perkebunan, diketahui $21,1 \%$ berada di luar areal yang diperuntukkan untuk perkebunan. Hal tersebut menunjukkan banyak perizinan yang tetap beroperasi meskipun tidak berada pada areal peruntukan yang telah ditetapkan oleh pemerintah.

Perubahan komposisi kawasan hutan yang paling besar terjadi sebagai akibat pemanfaatan dan penggunaan kawasan hutan secara legal dengan terbitnya perizinan berbasis lahan antara lain untuk izin perkebunan, pertambangan, pertanian serta izin pemanfaatan kawasan hutan sendiri. Tabel 2, Gambar 1, Gambar 2, dan Gambar 3 memberikan gambaran penggunaan kawasan hutan di Provinsi Riau, yang didominasi oleh perizinan perkebunan melalui skema pelepasan kawasan hutan, diikuti izin pemanfaatan hutan melalui skema IUPHHK-HTI serta penggunaan kawasan hutan melalui skema izin pinjam pakai (IPPKH). 


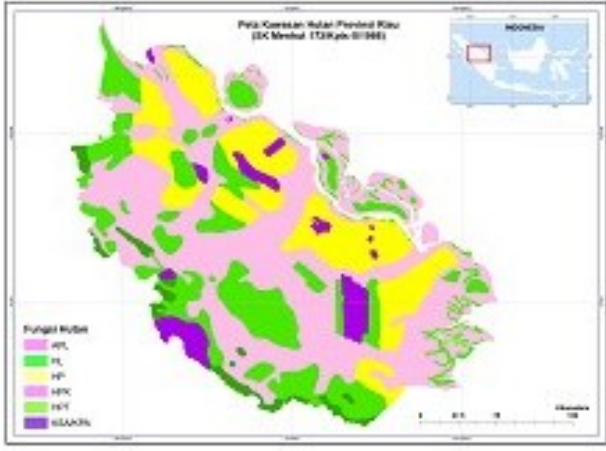

(a)

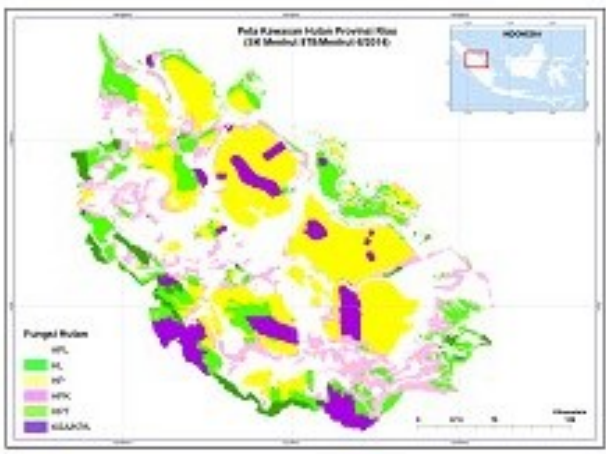

(d)

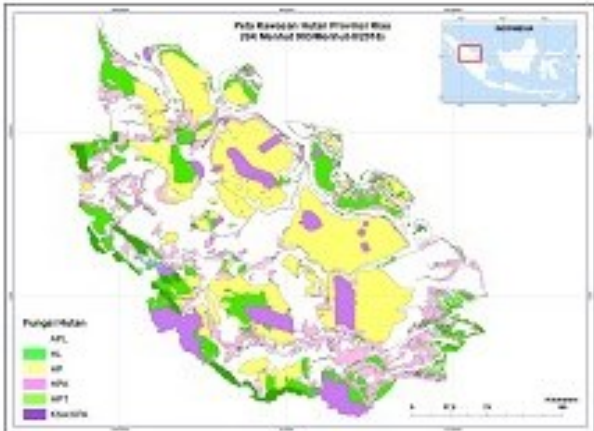

(e)
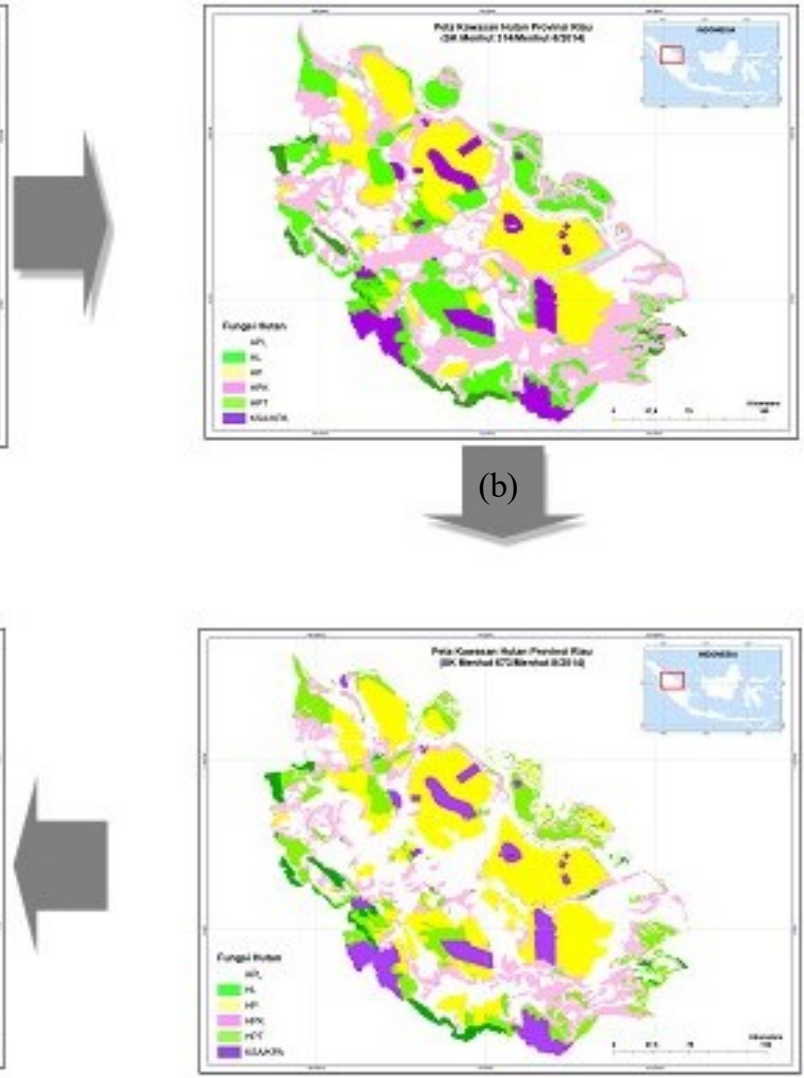

(c)

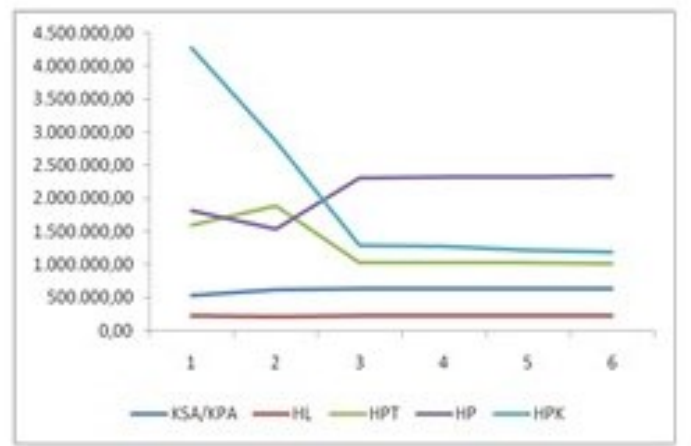

(f)

Sumber: Analisis Penulis, 2017

\section{Gambar 1. Transformasi Kawasan Hutan dan Grafik Perubahan Kawasan Hutan Provinsi Riau Tahun 1986-2016}

Keterangan :

(a) Peta Penunjukan Areal Hutan di Wil. Propinsi Dati I Riau Sebagai Kawasan Hutan sesuai SK Menhut No.SK.173/Kpts-II/1986

(b) Peta Perubahan Peruntukan Kawasan Hutan Menjadi Bukan Kawasan Hutan di Provinsi Riau sesuai SK Menhut No.SK.314/Menhut-II/2014

(c) Peta Perubahan Peruntukan KH Menjadi bukan KH, Perubahan Fungsi KH dan Penunjukan bukan KH menjadi KH Sesuai SK Menhut No.SK.673/Menhut-II/2014

(d) Peta Kawasan Hutan Provinsi Riau Sesuai SK Menhut No.SK.878/Menhut-II/2014

(e) Peta Kawasan Hutan Provinsi Riau sesuai SK Menteri LHK No. SK.903/SETJEN/PLA.2/12/2016

(f) Grafik Perbandingan Luas KH Berdasarkan Tahun Penunjukan 


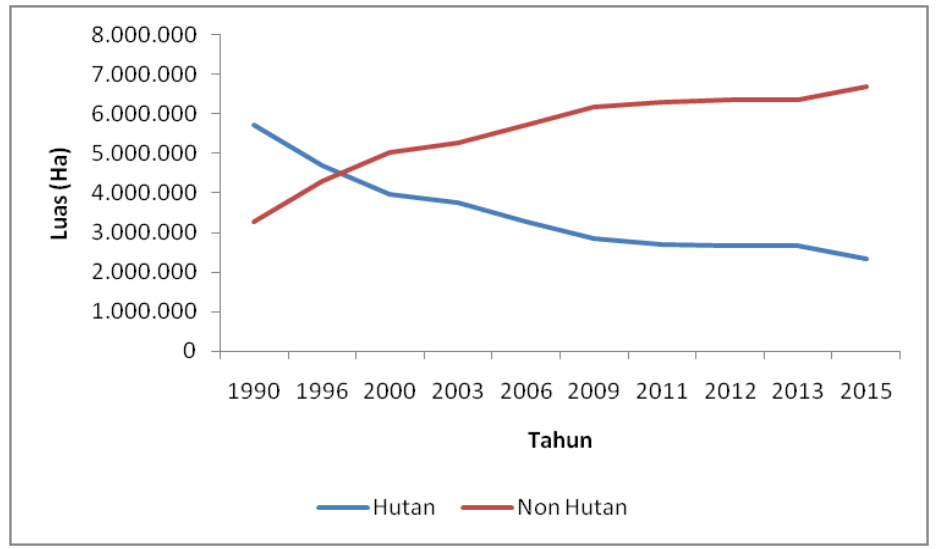

Sumber: Analisis Penulis, 2017

Gambar 2. Perubahan Komposisi Hutan dan Nonhutan di Provinsi Riau Tahun 1990-2015

Tabel 2. Penggunaan Kawasan Hutan di Provinsi Riau

\begin{tabular}{clcr}
\hline No & \multicolumn{1}{c}{ Perizinan Kawasan Hutan } & Jumlah Izin/Unit & Luas (Hektar) \\
\hline A & Kawasan Hutan & & \\
1 & IUPHHK-HA & 3 & 181.176 \\
2 & IUPHHK-RE & 4 & 116.977 \\
3 & IUPHHK-HTI & 56 & $1.612 .562,34$ \\
4 & IUPHHK-HTR & 7 & 4.192 \\
5 & IUPHHK-HD & 7 & 19.834 \\
6 & IUPHHK-HHBK & 2 & 29.418 \\
5 & Pinjam Pakai Kawasan Hutan & 17 & $8.107,171$ \\
B & APL dari HPK & 156 & $1.674 .123,78$ \\
1 & Perkebunan & 12 & $68.812,98$ \\
2 & Transmigrasi & 1 & 3.393 \\
3 & Pembangunan Teknopolitan & 265 & $3.718 .596,27$ \\
\hline
\end{tabular}

Sumber: Diolah dari data BPKH Wilayah XIX Pekanbaru, 2017

Berdasarkan data dari (Direktorat Jenderal Penegakan Hukum Dirjen PHKA, 2011) banyak terdapat penggunaan kawasan hutan nonprosedural di Provinsi Riau, dengan rincian untuk areal perkebunan sebanyak 98 unit dengan luasan 581 ribu hektar serta untuk areal pertambangan sebanyak 45 unit dengan luas 2.859 hektar. Penggunaan kawasan hutan nonprosedural adalah penggunaan kawasan hutan yang diperoleh tanpa memenuhi semua prosedur resmi yang telah diatur, biasanya dilakukan dengan memberikan sejumlah uang kepada pemberi izin (Setiawan et al., 2016). Munculnya kejadian ini salah satunya diakibatkan tidak selesainya proses paduserasi antara peta tata ruang kehutanan dan tata ruang provinsi (Setiawan et al., 2017). Menurut sumber Dinas Perkebunan Riau, banyak perusahaan perkebunan yang hanya memiliki izin lokasi (IL) dan izin usaha perkebunan (IUP), namun tidak memiliki izin pelepasan kawasan hutan dari Kemenhut. Selain itu, terdapat perusahaan yang sudah memiliki HGU tetapi tidak memiliki izin pelepasan kawasan hutan atau sebaliknya, karena terdapat areal yang sudah dilepaskan untuk perkebunan namun tidak segera diikuti dengan perolehan Hak Guna Usaha (HGU). 


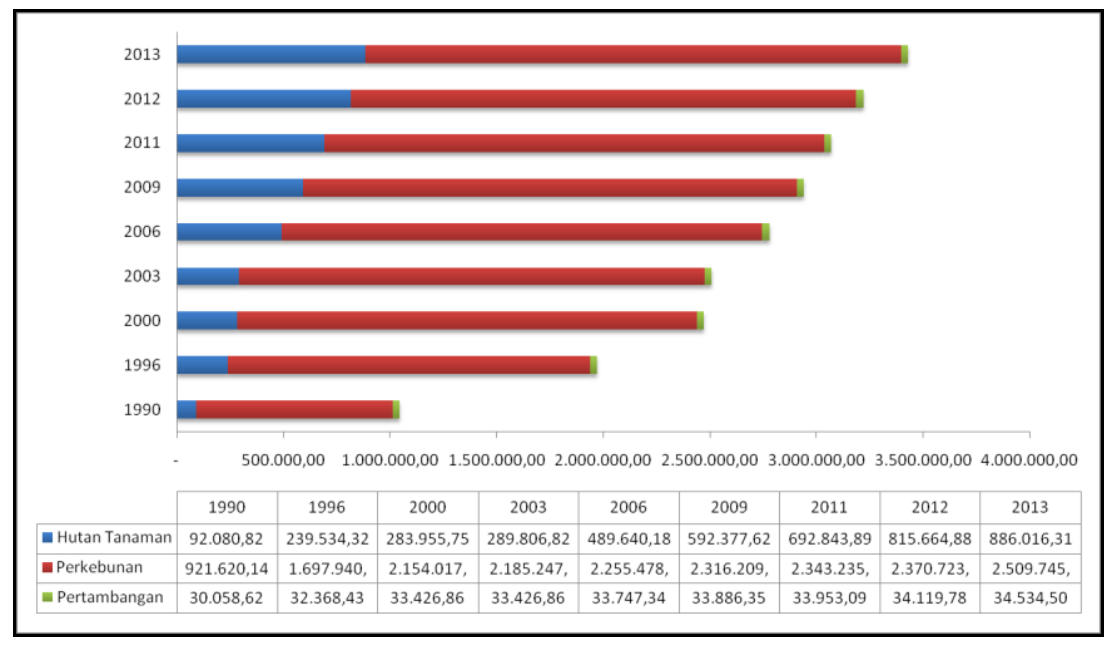

Sumber: Analisis Penulis, 2017

\section{Gambar 3. Perubahan Penutupan Lahan Berdasarkan Sektor Berbasis Lahan Tahun 1990-2013 di Riau}

\section{Penyelesaian Pelanggaran Prosedur Penggunaan Kawasan Hutan di Riau}

\section{Penyelesaian Melalui Skema PP Nomor 60/2012 jo PP Nomor 104/2015}

Peraturan Pemerintah (PP) Nomor 10 Tahun 2010 yang diamandemen dengan PP Nomor 60 Tahun 2012 dan PP Nomor 104 Tahun 2015 dalam pertimbangannya disebutkan bahwa aturan ini diterbitkan dalam rangka mendukung percepatan pembangunan di luar kehutanan. Dalam pasal 51 pemerintah memberikan kelonggaran terhadap investasi keterlanjuran. Terdapat dua poin krusial terkait investasi keterlanjuran yaitu:

1. Pasal (1) bahwa kegiatan usaha perkebunan dengan izin yang telah diterbitkan (izin terlanjur) oleh pemerintah daerah di kawasan hutan produksi (HP, HPT dan HPK) dalam waktu paling lama satu tahun sejak berlakunya PP ini dapat mengajukan permohonan pelepasan atau tukar-menukar kawasan hutan;

2. Pasal (2) ketika izin terlanjur oleh pemerintah daerah masuk areal kawasan dengan fungsi konservasi atau lindung menurut peta kawasan hutan terakhir, diberikan kesempatan untuk melanjutkan usaha selama satu daur tanaman pokok.

Berdasarkan data (Direktorat Jenderal Planologi Kehutanan dan Tata Lingkungan, 2017a) bahwa sampai dengan Agustus 2017 terdapat 40 perusahaan yang telah keluar SK Pelepasan Kawasan Hutan melalui skema PP Nomor 60 Tahun 2012 jo PP Nomor 104 Tahun 2015, baik melalui mekanisme tukar-menukar kawasan hutan maupun pelepasan kawasan hutan. Di Provinsi Riau sendiri dari 21 perusahaan yang mengajukan izin pelepasan kawasan hutan melalui skema aturan ini, yang sudah mendapatkan SK Menteri Kehutanan yaitu PT. Sawit Inti Raya dan PT. Teso Indah di Kabupaten Indragiri Hulu.

Meskipun dari segi jumlah perusahaan yang mendapatkan SK Pelepasan Kawasan Hutan terbilang sedikit, namun kedua poin perubahan dalam aturan tersebut setidaknya mencerminkan bahwa pemerintah secara tidak langsung telah memberikan dukungan terhadap pelanggaran sektor perkebunan. Hal ini tentu dapat menimbulkan konsekuensi terhadap proses investigasi pelanggaran yang dilakukan pihak perusahaan perkebunan oleh Kepolisian Indonesia, sehingga tidak dapat dilanjutkan (Setiawan et al., 2016). Data dari Eyes on the Forest (2016) mencatat setidaknya terdapat 26 perusahaan sawit yang beroperasi dalam kawasan hutan berdasarkan TGHK "diputihkan" menjadi APL melalui SK Menteri Kehutanan Nomor SK 878/Menhut-II/2014. 
Indrarto et al. (2012) menyatakan banyak lokasi yang sudah digunakan untuk perkebunan kelapa sawit, namun statusnya adalah hutan negara. Dari 2,4 juta hektar perkebunan kelapa sawit (Direktorat Jenderal Perkebunan Kementerian Pertanian Republik Indonesia, 2017), baru 1,6 juta hektar atau 70,8\% yang sudah mendapatkan izin pelepasan kawasan hutan (Direktorat Jenderal Planologi Kehutanan dan Tata Lingkungan Kementerian Kehutanan Republik Indonesia, 2016), dan 789 ribu hektar $(32,9 \%)$ yang sudah mendapatkan HGU (Dinas Perkebunan Provinsi Riau, 2016). Hal tersebut menunjukkan bahwa banyak perusahaan perkebunan yang tidak melalui prosedur pengurusan izin secara resmi dan benar. Hal ini diperkuat hasil penelitian yang dilakukan Setiawan et al. (2016) di Kalimantan Tengah yang menyatakan bahwa banyak izin perkebunan yang dikeluarkan pemerintah daerah tanpa melalui pelepasan kawasan hutan dari Kementerian Lingkungan Hidup Kehutanan (LHK)².

\section{Penyelesaian Melalui Mekanisme Holding Zone}

Istilah holding zone pertama kali muncul pada Instruksi Presiden (Inpres) Nomor 8 Tahun 2013 tentang Penyelesaian Penyusunan RTRW Provinsi dan Kabupaten/Kota pada era pemerintahan Presiden Susilo Bambang Yudhoyono. Dalam pertimbangannya, Inpres ini diterbitkan dalam rangka percepatan penyelesaian penyusunan RTRWP/K meskipun menimbulkan perdebatan dikarenakan dalam UU Nomor 26 Tahun 2007 sendiri tidak pernah diatur terkait ketentuan holding zone.

Penggunaan holding zone diakomodasi dalam Surat Rekomendasi Ombudsman Nomor 0002/REK/0361.2015/PBP-41/II/2016 kepada Pemerintah Provinsi Riau dalam mempercepat pembentukan RTRWP Riau untuk tetap menjamin kepastian hukum pembangunan. Adapun rincian holding zone sesuai dengan Ranperda Provinsi Riau tentang RTRWP Riau Tahun 2017-2037 dapat dilihat pada Tabel 3.

Tabel 3. Rincian Holding Zone dalam Ranperda RTRWP Riau 2017-2035

\begin{tabular}{|c|c|c|c|c|c|c|c|c|}
\hline \multirow{2}{*}{ No } & \multirow{2}{*}{$\begin{array}{c}\text { Peruntukan } \\
\text { Kawasan }\end{array}$} & \multicolumn{6}{|c|}{ Luas pada SK Nomor 903/2016 } & \multirow{2}{*}{ Luas (Ha) } \\
\hline & & HL & HP & HPK & HPT & KSA/KPA & APL & \\
\hline 1 & Permukiman & 3.415 & 7.309 & 6.315 & 3.563 & 1.852 & - & 19.317 \\
\hline 2 & $\begin{array}{l}\text { Infrastruktur, } \\
\text { Fasos dan } \\
\text { Fasum }\end{array}$ & 235 & 3.232 & 1.309 & 2.148 & 72 & - & 7.078 \\
\hline 3 & Industri & - & - & 306 & 93 & - & - & 399 \\
\hline 4 & $\begin{array}{l}\text { Perkebunan } \\
\text { Rakyat }\end{array}$ & 34.319 & 23.269 & 259.092 & 34.319 & 13 & & 321.717 \\
\hline 5 & Hutan Lindung & - & - & - & - & & 1.798 & 1.798 \\
\hline 6 & $\begin{array}{l}\text { Kawasan } \\
\text { Perikanan }\end{array}$ & - & - & - & 183 & - & - & 183 \\
\hline 7 & $\begin{array}{l}\text { Kawasan } \\
\text { Pertanian }\end{array}$ & ${ }_{5-}^{-}$ & 59 & 1.751 & 44.488 & $\begin{array}{c}9.056 \\
10008\end{array}$ & $\begin{array}{l}- \\
1708\end{array}$ & $\begin{array}{l}55.355 \\
405847\end{array}$ \\
\hline & Total & 5.596 & 35.562 & 311.592 & 49.363 & 10.908 & 1.798 & 405.847 \\
\hline
\end{tabular}

Berdasarkan sumber wawancara dengan Jikalahari (2017) di Riau, bahwa di dalam holding zone ini sebenarnya banyak mengakomodasi kepentingan pengusaha. Frislidia (2017) menyatakan bahwa dari temuan awal investigasi mereka menemukan holding zone masuk dalam areal korporasi dan cukong, yang artinya terjadi pelegalan terhadap kejahatan korporasi dan cukong yang beroperasi di dalam kawasan hutan tanpa pelepasan kawasan hutan.

\footnotetext{
${ }^{2}$ Kementerian Kehutanan berubah menjadi Kementerian Lingkungan Hidup dan Kehutanan berdasarkan Peraturan Presiden No. 16

Tahun 2015 tentang Kementerian Lingkungan Hidup dan Kehutanan 


\section{Kontestasi Aktor dalam Revisi RTRWP Provinsi Riau}

Konflik kepentingan hampir selalu mengiringi penentuan alokasi dan penggunaan lahan di kawasan hutan di Indonesia (Maryudi, 2015; Prabowo et al., 2017; Setiawan et al., 2016). Konflik secara empiris merupakan "the order of the day", dikarenakan sifat alamiah manusia yang selalu berbeda, selalu bertentangan (Lele, 2016). Salah satu hal yang menyebabkan konflik tersebut adalah banyaknya aktor dan kepentingan yang terlibat di dalamnya (Brockhaus et al., 2012). Dalam penataan ruang, antara pengusaha/investor, negara (pemerintah) dan masyarakat saling berinteraksi (Aminah, 2015). Melalui pengaruh yang dimilikinya, aktor tertentu dapat menentukan kontrol dan menjaga kemampuan untuk memperoleh manfaat dari sesuatu (Ribot \& Peluso, 2003). Aktor dapat bertindak sebagai perorangan, grup, aturan, institusi, pemerintah, negara atau perkumpulan masyarakat (Dahl, 1957). Dalam bahasa lain aktor disebut juga stakeholder (Barrow et al., 2002).

\section{Identifikasi Aktor dalam Revisi RTRWP Riau}

Berdasarkan hasil penelusuran dan wawancara di lapangan, setidaknya terdapat beberapa aktor yang terlibat dalam proses alokasi lahan dalam revisi RTRWP Riau beserta peran masing-masing (Tabel 4).

Tabel 4. Aktor dan Perannya dalam Proses Revisi RTRWP

\begin{tabular}{|c|c|c|c|}
\hline No & Aktor & Kedudukan Sebagai & Peran dan Fungsi \\
\hline \multirow[t]{16}{*}{1.} & Negara & Pemerintah Pusat & \\
\hline & & Kementerian LHK dan & Memberikan persetujuan substansi \\
\hline & & UPT & $\begin{array}{l}\text { Kajian Lingkungan Hidup Strategis } \\
\text { (KLHS) }\end{array}$ \\
\hline & & & $\begin{array}{l}\text { Terlibat dalam Tim Penelitian Terpadu } \\
\text { (Timdu) RTRWP }\end{array}$ \\
\hline & & Kementerian PU & Memberikan persetujuan substansi \\
\hline & & Kemendagri & Evaluasi Ranperda RTRWP \\
\hline & & DPR & Persetujuan perubahan yang Berdampak \\
\hline & & & $\begin{array}{l}\text { Penting dan Cakupan Luas serta Bernilai } \\
\text { Strategis (DPCLS) }\end{array}$ \\
\hline & & Pemerintah Daerah & Penyusunan Ranperda RTRWP \\
\hline & & Pemerintah Provinsi & Terlibat dalam Timdu RTRWP \\
\hline & & & Mengalokasikan Anggaran untuk Timdu \\
\hline & & & $\begin{array}{l}\text { Mengesahkan Ranperda RTRWP } \\
\text { bersama DPRD }\end{array}$ \\
\hline & & Tim Terpadu & Menyusun metodologi penelitian terpadu \\
\hline & & & Pengolahan dan analisis terhadap \\
\hline & & & perubahan fungsi $\mathrm{KH}$ dan Membuat \\
\hline & & & laporan kepada Menteri Kehutanan \\
\hline \multirow[t]{2}{*}{2.} & Swasta & Perusahaan HTI & Mengajukan perizinan per sektor \\
\hline & & Perusahaan Kebun & Ada indikasi sharing biaya RTRWP \\
\hline 3. & $\begin{array}{l}\text { Masyarakat/Lembaga } \\
\text { Swadaya Masyarakat }\end{array}$ & Masyarakat Riau & Mengawasi proses penyusunan RTRWP \\
\hline
\end{tabular}
Sumber: Analisis Penulis, 2017

Dalam melaksanakan peran dan fungsinya, setiap aktor memiliki mekanisme yang saling bertautan dan tidak dapat dipisahkan. Mekanisme kerja masing-masing aktor secara umum sebagaimana disajikan pada subbab alur proses revisi RTRWP berikut ini. 


\section{Alur Proses Review RTRWP}

Dalam UU Nomor 26 Tahun 2007 tentang Penataan Ruang telah diatur dengan jelas mekanisme dan proses penataan ruang nasional. Rencana tata ruang berlangsung secara hierarkis dan komplementer, dimulai dengan Rencana Tata Ruang Wilayah Nasional (RTRWN), kemudian diikuti RTRWP, RTRWK dan yang terakhir Rencana Detail Tata Ruang (RDTR). RTRWP memiliki jangka waktu 20 tahun dan dapat ditinjau kembali setiap lima tahun sekali.

Berdasarkan Peraturan Menteri Pekerjaan Umum (Permen PU) Nomor 15 Tahun 2009, dijelaskan bahwa secara garis besar penyusunan RTRWP terdiri dari proses dan prosedur penyusunan serta penetapan RTRWP (Gambar 4). Untuk mendapatkan penetapan RTRWP, terlebih dahulu harus dilakukan persetujuan substansi oleh menteri yang menyelenggarakan urusan pemerintahan di bidang penataan ruang (pasal $18 \mathrm{UU}$ Nomor 26 Tahun 2007 dan pasal 189 UU Nomor 32 Tahun 2004). Kemudian baru disetujui bersama antara pemerintah daerah provinsi dan DPRD Provinsi. Setelah ranperda disetujui lalu diajukan kepada Menteri Dalam Negeri untuk dievaluasi, untuk selanjutnya akan diproses pengesahannya ketika sudah ada persetujuan dari Mendagri.

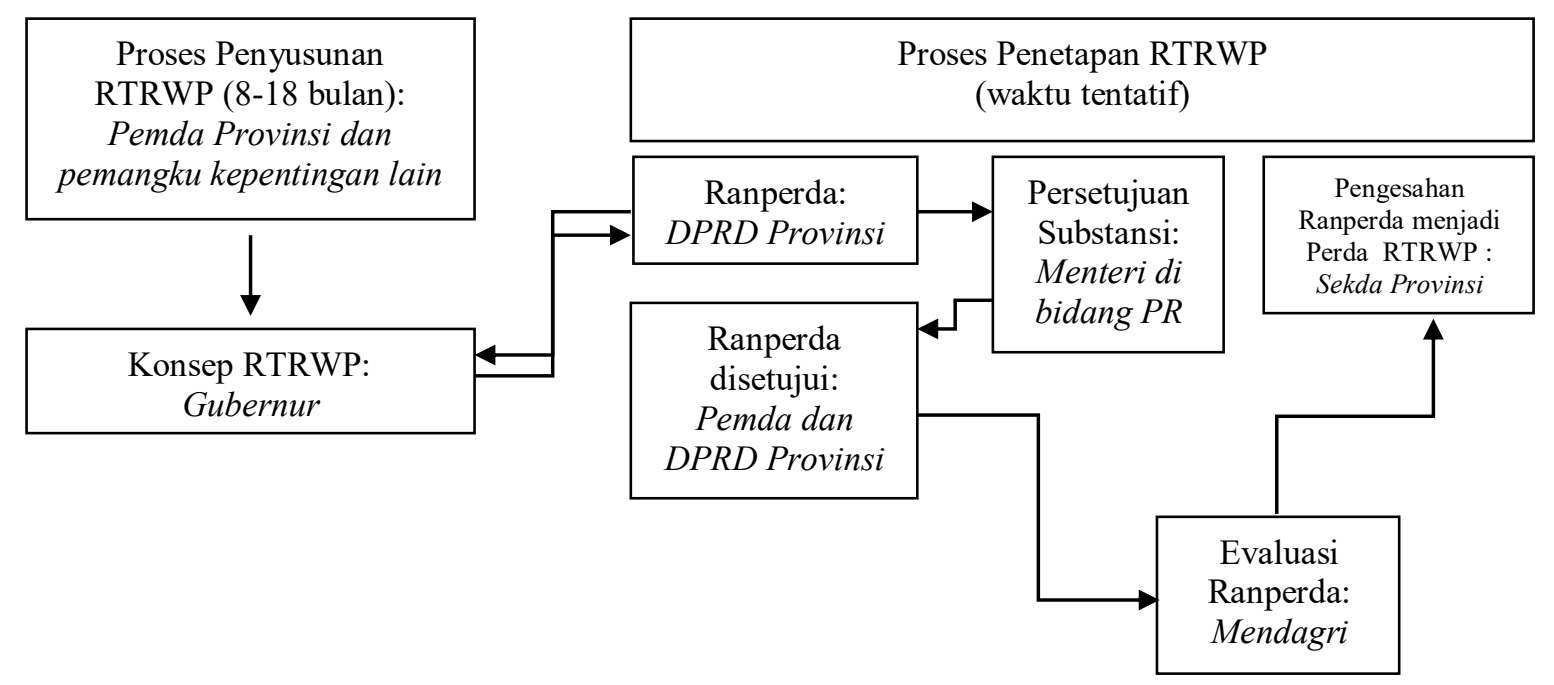

Sumber: Disarikan dari Undang-Undang Nomor 26 Tahun 2007

\section{Gambar 4. Alur Proses Penyusunan RTRWP}

Dalam proses persetujuan substansi oleh menteri terkait yang membidangi penataan ruang, Menteri Kehutanan akan berperan ketika terdapat perubahan kawasan hutan dalam review RTRWP (Direktorat Jenderal Planologi Kehutanan Kementerian Kehutanan Republik Indonesia, 2011). Hal ini dilakukan karena secara substansi RTRW berada di atas pola ruang kehutanan baik berupa kawasan lindung dan kawasan budidaya (UU Nomor 26 Tahun 2007). Dalam kawasan lindung terdapat kawasan hutan lindung, kawasan bergambut serta Kawasan Suaka Alam (KSA)/Kawasan Pelestarian Alam (KPA), sedangkan dalam kawasan budidaya terdapat kawasan hutan produksi. Dalam revisi RTRWP, apabila terdapat perubahan peruntukan kawasan hutan maka harus diproses melalui mekanisme UU Nomor 41 Tahun 1999 tentang Kehutanan serta PP Nomor 10 Tahun 2010 yang telah diperbarui dengan PP Nomor 60 Tahun 2012 dan PP Nomor 104 Tahun 2015 tentang Tata Cara Perubahan Peruntukan dan Fungsi Kawasan Hutan. Proses perubahan peruntukan kawasan hutan dapat dilakukan secara parsial atau melalui revisi RTRWP (pasal 6 PP Nomor 104 Tahun 2015). 
Pengertian kawasan hutan adalah wilayah tertentu yang ditetapkan oleh pemerintah untuk dipertahankan keberadaannya sebagai hutan tetap (Putusan MK Nomor 45/PUUIX/2011). Dalam penetapan suatu kawasan menjadi kawasan hutan diawali dengan penunjukan kawasan hutan kemudian proses penataan batas, pemetaan dan yang terakhir adalah penetapan kawasan hutan oleh Menteri Kehutanan. Mahkamah Konstitusi (2011) mengatakan bahwa proses penetapan kawasan hutan harus melibatkan berbagai pihak sebagai pemangku kepentingan.

Dalam proses penyesuaian revisi RTRWP, apabila berpotensi menimbulkan dampak atau risiko lingkungan, maka perlu dilakukan kajian lingkungan hidup strategis (KLHS) (lihat pasal 31 ayat 6 PP Nomor 104 Tahun 2015). Apabila perubahan peruntukan kawasan hutan dapat menimbulkan dampak penting dan cakupan luas serta bernilai strategis (DPCLS), maka pemerintah menyampaikan hasil penelitian tim terpadu kepada Dewan Perwakilan Rakyat (DPR) untuk mendapatkan persetujuan. Alur proses perubahan peruntukan kawasan hutan dapat dijelaskan dalam PP Nomor 104 Tahun 2015 (Gambar 5). Berdasarkan hal tersebut, maka diyakini bahwa terdapat hubungan linier antara pembangunan kehutanan dan pembangunan nasional dalam penyusunan revisi RTRWP yang diawali dengan proses paduserasi antara TGHK dan RTRWP (Syahadat \& Subarudi, 2012) sebagaimana ditampilkan pada Gambar 6.

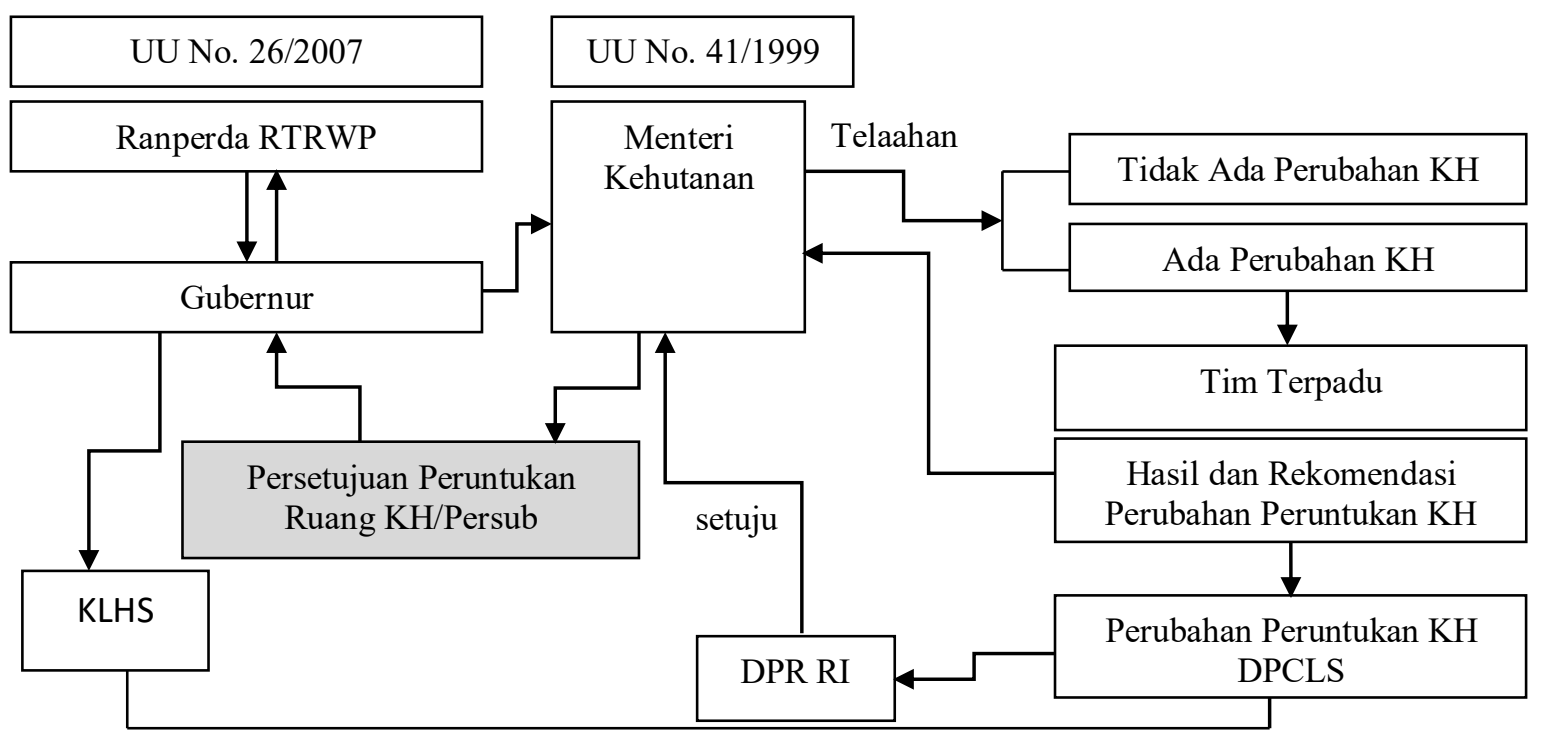

Sumber: PP Nomor 104 Tahun 2015

\section{Gambar 5. Alur Proses Persetujuan Substansi Kehutanan}

Penguasaan hutan oleh negara dengan memberikan wewenang kepada pemerintah untuk mengatur dan mengurus segala sesuatu yang berkaitan dengan hutan, kawasan hutan dan hasil hutan serta mengatur dan menetapkan hubungan-hubungan hukum antara orang dan hutan telah diatur dalam UU Nomor 41 Tahun 1999 pasal 4 ayat (2). Dengan adanya mandat ini, pemerintah berhak melakukan pengurusan hutan di satu sisi dan pengelolaan hutan di sisi lainnya. Dalam melakukan pengelolaan hutan, salah satu item yang dilaksanakan adalah pemanfaatan dan penggunaan kawasan hutan (lihat pasal 21 UU Nomor 41 Tahun 1999) untuk kegiatan kehutanan maupun di luar kehutanan. Kegiatan pemanfaatan kawasan hutan yang diberikan pemerintah antara lain pemberian izin usaha pemanfaatan hasil hutan kayu hutan alam/hutan tanaman (IUPHHK-HA/HTI). Adapun penggunaan hutan untuk pembangunan di luar kegiatan kehutanan dilakukan dengan 
mekanisme pinjam pakai kawasan hutan (Pasal 38 UU Nomor 41 Tahun 1999). Kedua item perizinan tersebut dilakukan melalui proses permohonan kepada Menteri Kehutanan.

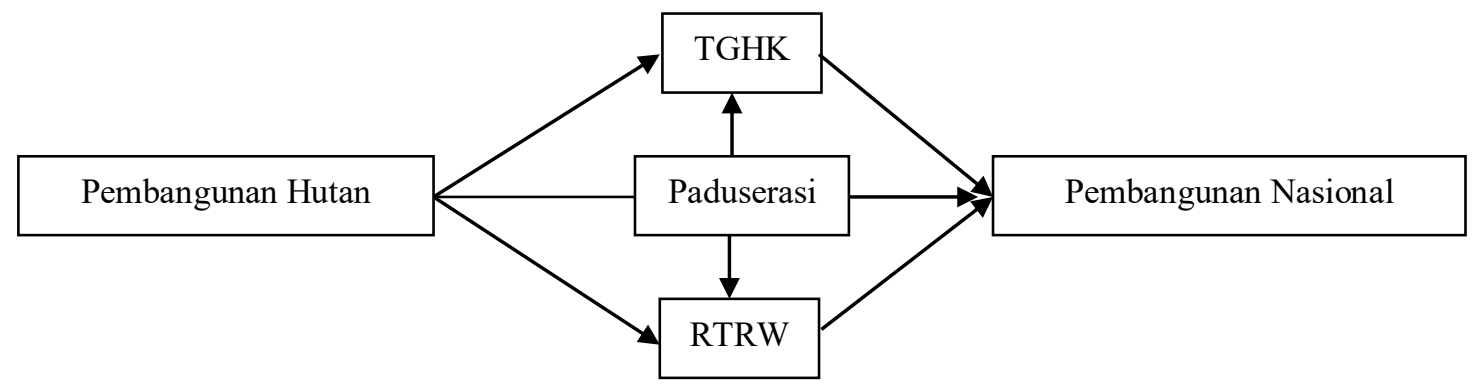

Sumber: Syahadat \& Subarudi, 2012

\section{Gambar 6. Keterkaitan Pembangunan Hutan dan Pembangunan Nasional Melalui Skema RTRWP}

\section{Penilaian Kekuasaan Aktor dalam Revisi RTRWP Riau}

Setelah melakukan identifikasi aktor yang terlibat dilakukan analisis dan penilaian pengaruh masing-masing aktor. Gambar 7 menggambarkan penilaian pengaruh masingmasing aktor, yaitu pemerintah pusat (Kementerian LHK, Kemen PU, Kemendagri), tim terpadu (Timdu), pemerintah daerah provinsi dan kabupaten, perusahaan, dan masyarakat.

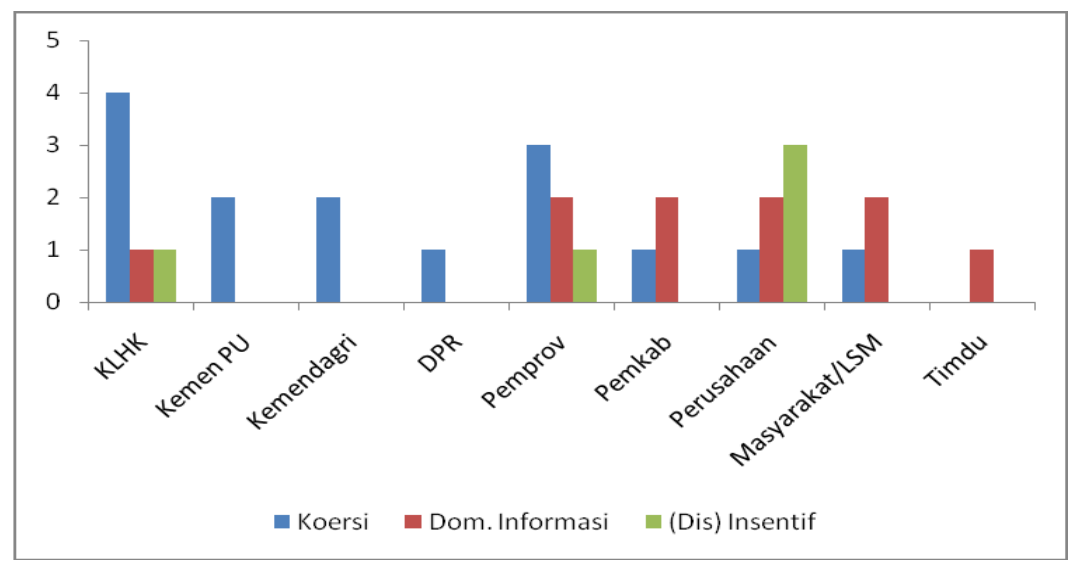

Sumber: Analisis Penulis, 2017

Gambar 7. Perhitungan PowerAktor dalam Revisi RTRWP Riau

Dalam pembahasan berikut ini akan diuraikan aktor dan perannya masing-masing dalam proses pembahasan revisi RTRWP Riau Tahun 2017-2035 terutama terkait sektor berbasis lahan (kehutanan dan perkebunan).

Kuatnya Peran Kementerian Lingkungan Hidup dan Kehutanan (LHK) dan Melemahnya Peran Pemerintah Daerah

Ruang dapat berperan dalam berbagai fungsi antara lain fungsi sosial, ekonomi dan politik yang melibatkan pengusaha, negara (pemerintah) dan masyarakat (Aminah, 2015). Selanjutnya Aminah (2015) menyebutkan bahwa kekuasaan pemerintah dalam penataan ruang dimanifestasikan dalam tahapan perencanaan, pemanfaatan, dan 
pengawasan/pengendalian. Kontestasi aktor dalam penataan ruang sering menjadi penyebab kerusakan sumber daya alam (Kartodiharjo, 2010), antara lain terlihat dalam pertarungan penetapan arahan ruang untuk investor yang salah satunya diakibatkan telah terbitnya berbagai izin oleh pemerintah daerah (gubernur/walikota/bupati) sebagai akibat desentralisasi (Barr et al., 2006; Myers \& Ardiansyah, 2014). Brockhaus et al. (2012) memperkuat pernyataan tersebut bahwa proses dan kebijakan alokasi lahan di Indonesia didominasi oleh adanya konflik kepentingan, kelembagaan yang kurang jelas dan kurangnya koordinasi antarlembaga serta adanya saling tumpang-tindih dan mandat yang saling bertentangan (Maryudi, 2015).

Kementerian LHK merupakan aktor yang memiliki pengaruh lebih besar daripada pemerintah daerah provinsi dan kabupaten dalam revisi RTRWP. Melalui pengaruh koersinya, Kementerian LHK dapat menetapkan status suatu kawasan hutan melalui keputusan Menteri Lingkungan Hidup dan Kehutanan. Adapun pemerintah daerah menggunakan koersi mereka untuk memberikan rekomendasi alokasi untuk perizinan berbasis lahan yang ada di daerah mereka dalam rencana revisi RTRWP Riau, serta menggunakan informasi dominan untuk mempengaruhi Kementerian LHK dalam menentukan alokasi lahan dalam persetujuan substansi kehutanan.

Terjadinya gesekan kepentingan di Provinsi Riau dalam penyelesaian RTRWP tidak terlepas adanya proses sinkronisasi RTRWP pada tahun 1994 dengan TGHK yang tidak selesai pada tahun 1997 (Kartodiharjo, 2010). Seperti diungkapkan Wibowo \& Giessen (2015) bahwa dengan tidak selesainya sinkronisasi RTRWP dengan TGHK menyebabkan adanya ketidakpastian dalam penggunaan lahan, sehingga secara otomatis kewenangan akan kembali ke Kemenhut.

Berdasarkan UU Nomor 41 Tahun 1999 segala sesuatu yang berurusan dengan penataan ruang kawasan hutan tetap didasarkan pada penunjukan kawasan hutan dan perairan yang ditetapkan oleh Menteri Kehutanan (Brockhaus et al., 2012). Kewenangan yang kuat dari Kemenhut terhadap alokasi lahan di Riau dimulai semenjak ditetapkannya peta TGHK sebagai pedoman tata ruang. Kewenangan Kemenhut terlihat dengan dikeluarkannya SE Nomor 404/Menhut-II/2003 yang mengembalikan pedoman penataan ruang kehutanan kepada TGHK sebagai akibat tidak selesainya paduserasi di Riau.

Menguatnya kewenangan Kementerian LHK semakin tampak jelas dengan berlarutlarutnya proses pengesahan RTRWP Riau Tahun 2017-2037 yang memerlukan persetujuan substansi kehutanan. Proses perubahan kawasan hutan yang memerlukan persetujuan Menteri Kehutanan menjadi titik krusial perjalanan review RTRWP (Gambar 5). Dari alur proses persetujuan substansi tersebut dapat dilihat meskipun aturan tata ruang yang digunakan berbeda, hasil akhir yang akan diperoleh adalah persetujuan Menteri Kehutanan terhadap perubahan peruntukan yang diajukan oleh Gubernur. Hal inilah yang selalu menjadi persoalan yang sulit untuk menemukan kesepakatan kedua belah pihak. Sebagaimana diilustrasikan dalam Gambar 3, Gubernur Riau mengajukan 3,5 juta hektar kawasan hutan untuk diubah menjadi penggunaan nonkehutanan (Tim Terpadu, 2012), namun yang disetujui oleh Menteri Kehutanan hanya 1,6 juta hektar (SK Menhut Nomor 673/2014 dan diikuti SK Menhut Nomor 878/2014). Berdasarkan hasil wawancara dengan Dinas Lingkungan Hidup dan Kehutanan, meskipun Pemerintah Provinsi Riau merasa keberatan, namun mereka tidak pernah mengajukan keberatan secara hukum sehingga keputusan ini tetap berlaku.

Menurut pernyataan Menteri LHK dalam koran webpage Jawa Pos sebenarnya tugas Kementerian LHK terkait RTRWP Riau telah selesai dibahas dengan keluarnya SK Nomor 673/2014, namun SK ini tidak mau dijalankan oleh Pemerintah Provinsi Riau. Sementara itu, Pemerintah Provinsi Riau bersikeras menginginkan penambahan alih fungsi kawasan hutan sesuai permintaan mereka, padahal RTRWP merupakan dasar hukum yang kuat bagi daerah untuk mengelola wilayah yang menjadi kewenangan mereka (Wibowo \& Giessen, 2015). Hasil wawancara dengan informan Dinas LHK Riau dan Dinas Perkebunan Riau 
menerangkan bahwa berlarutnya penyelesaian review RTRWP ini diperkirakan akan menghambat investasi di Riau. Lebih lanjut dijelaskan Wibowo \& Giessen (2015), belum selesainya RTRWP ini membuat kawasan hutan tetap berada di bawah pengawasan Kementerian Kehutanan. Myers \& Ardiansyah (2015) menambahkan bahwa meskipun kekuasaan dan tanggung jawab sudah terdesentralisasi sejak tahun 1998, namun pengambilan keputusan terkait dengan kawasan hutan tetap berada di pusat (Kementerian LHK). Hal ini menandakan betapa kontrasnya perbedaan asumsi antara UU Otonomi daerah dan UU Kehutanan yang sangat terpusat ke pemerintah pusat (Barr et al., 2006).

\section{Tim Penelitian Terpadu RTRWP Riau dan Peran Yang Diemban}

Dalam penyusunan RTRWP tidak terlepas adanya perubahan peruntukan dan fungsi kawasan hutan sebagaimana ditampilkan dalam Gambar 5. Mengacu pasal 19 ayat (1) UU Nomor 41/1999, proses perubahan peruntukan dan fungsi kawasan hutan dalam review RTRWP ditetapkan oleh pemerintah dengan didasarkan pada hasil penelitian Timdu. Pembentukan Timdu dalam proses perubahan peruntukan kawasan hutan didasarkan pada Permenhut Nomor P.36/Menhut-II/2010. Timdu beranggotakan orang-orang yang memiliki kompetensi dan otoritas ilmiah (scientific authority). Keanggotaan serta fungsi yang melekat pada Timdu seharusnya membuat tim ini menjadi sangat krusial dalam penentuan perubahan peruntukan kawasan hutan.

Timdu RTRWP Riau ditetapkan dengan SK Menteri Kehutanan Nomor 410/menhutVII/2009 yang kemudian diperbarui dengan SK Menteri Kehutanan No.512/MenhutVII/2010. Revisi keputusan Timdu dilakukan untuk menambah anggota Timdu di bidang sosial sebagai akibat banyaknya persoalan sosial yang mengiringi review RTRWP Riau.

Hasil kerja Timdu yang tertuang dalam Surat Pengantar Nomor : 001/RTRWPRiau/Timdu/2012 beserta laporan Timdu Riau menyatakan bahwa secara keseluruhan luas perubahan peruntukan kawasan hutan menjadi APL seluas 2.740.586 hektar, perubahan fungsi 709.184 hektar, dan penunjukan kawasan hutan 13.685 hektar. Dari hasil rekomendasi Timdu, Kemenhut dapat menyetujui perubahan peruntukan kawasan hutan menjadi APL seluas 1.638.249 hektar (59\%), perubahan fungsi 717.543 hektar (98\%), dan penunjukan kawasan hutan 11.552 hektar (65\%). Perbandingan antara usulan pemerintah daerah, hasil Timdu dan persetujuan Kemenhut tersaji pada Gambar 8.

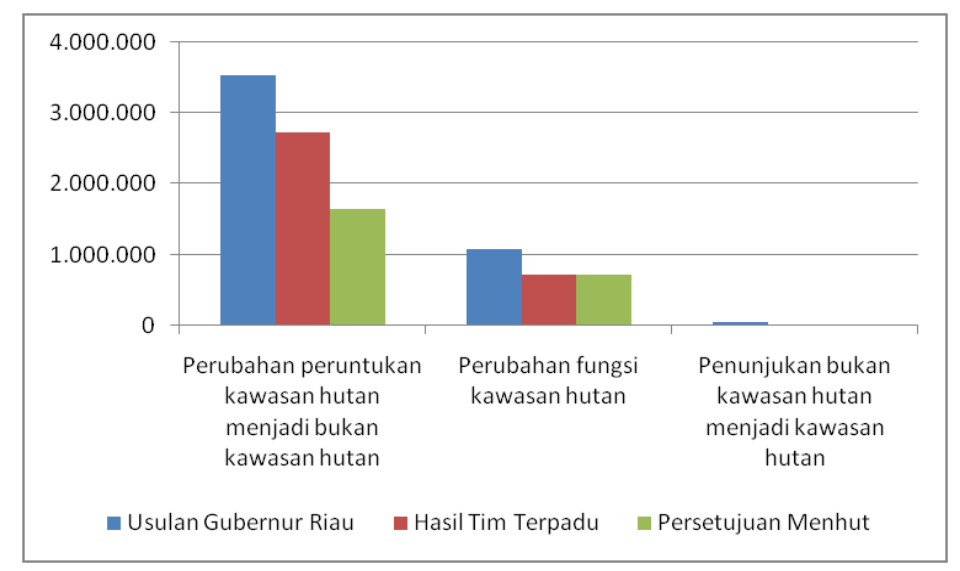

Sumber: Analisis Penulis, 2017

\section{Gambar 8. Perbandingan Usulan Pemda, Hasil Timdu dan Persetujuan Menteri dalam Review RTRWP Riau}

Dari Gambar 8 dapat dilihat bahwa keputusan Timdu yang memiliki scientific authority masih dapat ditolak oleh Menteri Kehutanan. Ombudsman Republik Indonesia 
(2016) dalam suratnya menyatakan bahwa alasan Kementerian Kehutanan menerbitkan SK yang tidak sesuai usulan Timdu dikarenakan memiliki management authority. Berdasarkan informasi Ditjen Planologi Kehutanan dalam Rapat Dengar Pendapat dengan Komisi IV (Direktorat Jenderal Planologi Kehutanan dan Tata Lingkungan, 2017b), bahwa Kemenhut dapat menyetujui seluruh atau kurang dari usulan yang direkomendasikan oleh timdu, akan tetapi tidak boleh melebihi usulan dari timdu.

Kewenangan Timdu yang terbatas ini, menurut asumsi kami disebabkan oleh aturan yang menegaskan bahwa Timdu dibentuk melalui SK Menteri Kehutanan. Melalui aturan ini diperkirakan akan mengurangi independensi dari Timdu tersebut. Alasan kedua adalah terkait anggaran yang digunakan oleh Timdu. Dalam aturan juga dijelaskan bahwa anggaran penyelenggaraan Timdu sampai disusunnya laporan sementara dibebankan kepada pemerintah daerah provinsi selaku pemohon (lihat Pasal 25 Permenhut Nomor P.36/2010). Dengan keterbatasan anggaran tentunya akan mengurangi jangkauan keterwakilan lokasi yang dikunjungi oleh Timdu, yang akhirnya akan mengurangi tingkat validitas data lapangan.

\section{Munculnya Peran Ombudsman, Swasta dan Lembaga Swadaya Masyarakat}

Terbitnya SK Menteri Kehutanan Nomor SK.673 Tahun 2014 dan SK Menteri Kehutanan Nomor SK.878 Tahun 2014 menimbulkan gejolak di Provinsi Riau (Gilang Fauzi, 2014). Pemerintah Riau berkeberatan dengan keputusan Menteri Kehutanan tersebut karena hasil Timdu tidak seluruhnya disetujui dan mengajukan gugatan melalui Ombudsman RI. Dengan menggunakan aturan hukum UU Nomor 37 Tahun 2008 tentang Ombudsman RI, beberapa temuan terkait persoalan administrasi dalam penerbitan SK Menhut tersebut dapat diungkap.

Beberapa rekomendasi dari hasil peninjauan lapangan oleh Ombudsman antara lain: pertama, terjadi kesalahan administrasi yang signifikan dari penyelesaian usulan peruntukan dan fungsi kawasan hutan dalam revisi RTRWP Riau, terkait selisih waktu antara ekspos Timdu dan terbitnya SK Menhut Nomor 673 Tahun 2014. Kedua, terbitnya SK Menhut Nomor 673 Tahun 2014 dan SK Menhut Nomor 878 Tahun 2014 telah menimbulkan ketidakpastian hukum dalam penyelenggaraan pelayanan publik di provinsi dan kabupaten/kota. Hal ini diungkapkan juga oleh informan Badan Pertanahan Nasional (BPN) dan Dinas Energi dan Sumber Daya Mineral (ESDM) Provinsi Riau yang mengatakan bahwa belum tercapainya titik temu pemerintah provinsi dengan Kementerian LHK dapat mengganggu kepastian investasi di Riau.

Meskipun secara aturan rencana tata ruang menjadi kewenangan penuh pemerintah atau negara, namun beberapa NSA memiliki kemampuan untuk menyusun agenda politik dan ekonomi global (Higgot, Underhill, \& Bieler, 2000). NSA dapat diidentifikasi sebagai aktor perusahaan sektor privat/swasta maupun LSM. Hasil penilaian dengan ACP mengungkap bahwa masyarakat menggunakan elemen pengaruh informasi dominan untuk memberikan masukan kepada pihak pemerintah daerah. Selain pemerintah, aktor yang terlibat di dalam tata ruang antara lain investor maupun masyarakat. Lebih lanjut Myers \& Ardiansyah (2015) mengatakan bahwa meskipun secara keseluruhan pemerintah memiliki kewenangan yang sangat besar terhadap perubahan penggunaan lahan, namun perusahaan swasta juga memiliki pengaruh secara formal dan informal terhadap pengambilan keputusan tata guna lahan.

Dalam RTRWP, peran swasta (perusahaan) tampak jelas dengan terungkapnya kasus alih fungsi lahan oleh pengusaha Edison Marudut Siahaan dan Gulat Manurung dengan bendera perusahaan Duta Palma (Riyan Novitra, 2016). Hal ini menandakan bahwa perusahaan menggunakan pengaruh insentif untuk mempengaruhi keputusan pemerintah dalam mengalokasikan lahan untuk mereka. Hal serupa juga ditemukan oleh Prabowo et al. (2017) dan Setiawan et al. (2017) di Kalimantan, serta Situmorang \& Kartodiharjo (2016) 
yang menemukan adanya pemberian sejumlah uang dalam praktik alokasi lahan untuk perusahaan.

Menurut informan dari Koalisi Rakyat Riau, terdapat 33 perusahaan kelapa sawit yang diubah dari kawasan hutan menjadi APL dalam draf RTRWP Riau 2016-2035. Hal serupa juga ditambahkan oleh Frislidia (2017) yang menemukan areal korporasi dan cukong dalam holding zone RTRWP Riau. Hal ini dapat menjadi indikasi bahwa banyak perusahaan melakukan upaya nonprosedural untuk mendapatkan alokasi lahan dengan insentif tertentu (Prabowo et al., 2017; Setiawan et al., 2016).

Dalam laporan Timdu diketahui bahwa banyak kawasan hutan yang dirubah fungsinya menjadi APL dikarenakan telah terbitnya izin penggunaan kawasan hutan oleh Bupati/Pemda walaupun tanpa pelepasan kawasan hutan sebelumnya (Tim Terpadu, 2012), padahal apabila melihat Peraturan Menteri Pekerjaan Umum No.15 Tahun 2008 dikatakan bahwa peninjauan kembali dan revisi RTRWP dilakukan bukan untuk pemutihan terhadap penyimpangan pemanfaatan ruang di wilayah provinsi.

Munculnya peran besar LSM juga terlihat dalam proses pengesahan RTRWP 20162035 ini (Hukrim, 2017). Jikalahari sebagai salah satu LSM di Riau menuntut agar pengesahan RTRWP Riau ditunda untuk mengakomodasi beberapa peraturan yaitu Perpres Nomor 88 Tahun 2017, PP Nomor 57 Tahun 2016 serta Permen LHK Nomor 17 Tahun 2017 tentang perlindungan dan pengelolaan ekosistem gambut (Hukrim, 2017). Meskipun tidak seluruhnya menjadi penyebab tertundanya pengesahan ranperda RTRWP, namun tekanan dari beberapa LSM lingkungan di Riau mendapatkan perhatian serius dalam RTRWP Riau. Hal ini menandakan bahwa pertarungan antar aktor dalam proses tata ruang akan membenturkan sektor-sektor yang berorientasi pada produksi seperti perkebunan, pertambangan dan kehutanan dengan sektor yang berorientasi konservasi (Wibowo \& Giessen, 2015).

\section{Kesimpulan}

Provinsi Riau merupakan salah satu dari dua provinsi di Indonesia yang tidak menyelesaikan proses paduserasi TGHK dengan RTRWP. Persoalan ini kemudian menjadi pangkal permasalahan yang lebih besar terkait dengan tarik-ulur kepentingan sektoral di Riau. Berlarut-larutnya proses penyusunan Ranperda RTRWP Riau Tahun 2017-2035 menjadi gambaran betapa rumitnya kontestasi kepentingan berbagai pihak.

Masing-masing aktor di dalam pemerintahan sendiri masih bersikukuh menggunakan aturan yang melekat dan menjadi mandat mereka. Pemerintah Pusat (Kementerian LHK) mengacu pada UU Nomor 41 Tahun 1999 tentang Kehutanan sedangkan pemerintah daerah mengacu pada UU Nomor 26 Tahun 2007 terkait tata ruang mereka. Secara prosedural, pemerintah daerah maupun pemerintah pusat telah melalui masing-masing tahapan yang termaktub dalam aturan yang ada. Meskipun pada awalnya berdasarkan aturan UU Nomor 22 Tahun 1999 pemerintah daerah diberi kewenangan mengatur alokasi lahan di daerahnya (Contreras-Hermosilla \& Fay, 2006; Sahide \& Giessen, 2015), namun kemunculan UU Nomor 23 Tahun 2014 menyebabkan kewenangan alokasi lahan kehutanan dikembalikan kepada pemerintah pusat (Steni, 2016; Sahide et al., 2016).

Tulisan ini setidaknya memberikan gambaran bahwa proses alokasi lahan dalam revisi RTRWP Riau sangat dipengaruhi oleh keterlibatan aktor dengan berbagai kepentingan masing-masing. Hal ini memperkuat teori power/pengaruh yang dikemukakan oleh para pakar, bahwa pengaruh merupakan kemampuan seseorang untuk mempengaruhi tindakan orang lain yang berada dalam jaringan mereka serta dapat diobservasi.

Salah satu win-win solution yang tertuang dalam Inpres Nomor 8 Tahun 2013 tentang Penyelesaian Penyusunan RTRW Provinsi dan Kabupaten/Kota dan rekomendasi Ombudsman melalui implementasi holding zone juga belum menemukan titik terang. 
Beberapa catatan LSM di Riau yang melakukan penelusuran di lapangan menemukan indikasi adanya campur tangan korporasi dan cukong dalam areal holding zone tersebut.

Kementerian LHK masih menjadi institusi yang paling kuat dalam kontestasi ini, dengan kewenangan yang besar terhadap pengelolaan kawasan hutan di Riau. Melalui PP Nomor 104 Tahun 2015, pemerintah pusat (Kementerian LHK) banyak memberikan keleluasaan bagi beberapa pelanggaran yang dilakukan oleh perusahaan yang beroperasi di dalam kawasan hutan. Dari penelitian ini juga terungkap munculnya peran Ombudsman dengan mandat dari UU Nomor 37 Tahun 2008, dan NSA (swasta dan LSM) dalam proses penyusunan Ranperda RTRWP Riau. Beberapa rekomendasi yang dapat diberikan dalam menyelesaikan permasalahan revisi RTRWP Riau antara lain: 1) koordinasi dan integrasi antaraktor baik pemerintah, swasta dan LSM, serta sikap keterbukaan dari masing-masing sektor untuk melakukan kerjasama yang lebih baik. Kebijakan integratif antarsektor sebagaimana dikatakan Giessen \& Krott (2009) merupakan alternatif kebijakan yang sebenarnya dapat meminimalkan tumpang-tindih dan ego sektoral; 2) penegakan hukum terhadap segala tindakan yang mempunyai indikasi pelanggaran hukum; dan 3) perlunya pengelolaan konflik dimasukkan sebagai elemen dalam RTRW.

\section{Daftar Pustaka}

Aminah, S. (2015). Konflik dan kontestasi penataan ruang Kota Surabaya. Masyarakat: Jurnal Sosiologi, 20(1), 59-79. Retrieved from http://journal.ui.ac.id/index.php/mjs/article/view/4751.

Aurenhammer, P. K. (2013). Development cooperation policy in forestry from an analytical perspective. Dordrecht, Netherlands: Springer Science \& Business Media.

Barr, C., Resosudarmo, I. A. P., Dermawan, A., MacCarthy, J., Moeliono, M., \& Setiono, B. (2006). Decentralization of forest administration in Indonesia in Implications. Implications for forest sustainability, economic development and community livelihoods. (C. Barr, I. A. P. Resosudarmo, A. Dermawan, \& J. McCarthy, Eds.). Bogor, Indonesia: Center for International Forestry Research. Retrieved from https://www.cifor.org/library/2113/.

Barrow, E., Clarke, J., Grundy, I., Jones, K.-R., \& Tessema, Y. (2002). Analysis of stakeholder power and responsibilities in community involvement in forest management in Eastern and Southern Africa. Nairobi, Kenya. Retrieved from https://www.iucn.org/content/analysis-stakeholder-power-and-responsibilitiescommunity-involvement-forest-management.

Brockhaus, M., Obidzinski, K., Dermawan, A., Laumonier, Y., \& Luttrell, C. (2012). An overview of forest and land allocation policies in Indonesia: Is the current framework sufficient to meet the needs of REDD+? Forest Policy and Economics, 18, 30-37. doi:10.1016/j.forpol.2011.09.004.

Casson, A. (2000). The Hesitant boom: Indonesia's oil palm sub-sector in an era of economic crisis and political change. Bogor, Indonesia. doi:10.17528/cifor/000625.

Casson, A., Tacconi, L., \& Deddy, K. (2007). Strategies to reduce carbon emissions from the oil palm sector in Indonesia. Bali.

Clapham, A. (2016). Non-state actors. In D. Moeckli, S. Shah, S. Sivakumaran, \& D. Harris (Eds.), International Human Rights Law (3rd (Forth). Oxford: Oxford University Press. Retrieved from https://papers.ssrn.com/sol3/papers.cfm?abstract_id=1626284.

Clunie, N., \& Applegate, G. B. (1994). Functional categorisationfor sustainable forest management (No. 2). Jakarta.

Colfer, C. J. P., Dahal, G. ., \& Capistrano, D. (2009). Pelajaran dari desentralisasi kehutanan: mencari tata kelola yang baik dan berkeadilan di Asia-Pasifik. Bogor, Indonesia. doi:10.17528/cifor/002653.

Contreras-Hermosilla, A., \& Fay, C. C. (2006). Memperkokoh pengelolaan hutan Indonesia melalui pembaruan penguasaan tanah: Permasalahan dan kerangka tindakan. Bogor, Indonesia: Bogor World Agroforestry Center dan Forest Trends. from http://www.worldagroforestry.org/publication/memperkokoh-pengelolaan-hutan-indonesia-melaluipembaruan-penguasaan-tanah-permasalahan.

Dahl, R. A. (1957). The concept of power. Behavioral Science: Journal of Society for General Systems Research, 2(3), 201-215. doi:10.1002/bs.3830020303. 


\section{Kontestasi Aktor dalam Proses Revisi Rencana Tata Ruang Provinsi (RTRWP) di Indonesia ...}

Dinas Perkebunan Provinsi Riau. (2016). Data perizinan perusahaan perkebunan Provinsi Riau. Riau: Dinas Perkebunan Provinsi Riau.

Direktorat Jenderal Penegakan Hukum Dirjen PHKA. (2011). Penggunaan kawasan hutan tidak prosedural. Jakarta.

Direktorat Jenderal Perkebunan Kementerian Kehutanan Republik Indonesia. (2017). Statistik perkebunan Indonesia 2015-2017. Setditjen Perkebunan, Ditjen Perkebunan, Republik Indonesia.

Direktorat Jenderal Planologi Kehutanan dan Tata Lingkungan. (2017a). Data perkembangan proses pelepasan KH melalui skema PP Nomor 60 Tahun 2012/Pasal 51 PP Nomor 104 Tahun 2015. Jakarta.

Direktorat Jenderal Planologi Kehutanan dan Tata Lingkungan. (2017b). Rapat dengar pendapat (RDP) direktur jenderal planologi kehutanan dengan Komisi IV DPR RI. Jakarta.

Direktorat Jenderal Planologi Kehutanan dan Tata Lingkungan Kementerian Kehutanan Republik Indonesia. (2016). Data dan informasi ditjen planologi kehutanan dan tata lingkungan. Direktorat Jenderal Planologi Kehutanan dan Tata Lingkungan.

Direktorat Jenderal Planologi Kehutanan Kementerian Kehutanan Republik Indonesia. (2011). Review RTRWP dan penggunaan Kawasan Hutan. Kementerian Kehutanan.

Esterberg, K. (2002). Qualitative methods in social research. New York: McGraw-Hill.

Eyes on the Forest. (2016). 'Legalisasi' perusahaan sawit melalui perubahan peruntukan kawasan hutan menjadi bukan kawasan hutan di Provinsi Riau (2). Retrieved October 17, 2017, from https://www.eyesontheforest.or.id/reports/legalisasi-perusahaan-sawit-melalui-perubahan-peruntukankawasan-hutan-menjadi-bukan-kawasan-hutan-di-provinsi-riau-2-maret-2018.

Food and Agriculture Organization (FAO). (2010). Developing effective forest policy - A guide (FAO Forestry Paper 161). Rome. Retrieved from http://www.fao.org/docrep/013/i1679e/i1679e00.htm.

Frislidia. (2017). Jikalahari Desak DPRD Riau tolak draft RTRW, ini alasannya. Retrieved October 17, 2017, from https://riau.antaranews.com/berita/86481/jikalahari-desak-dprd-riau-tolak-draft-rtrw-inialasannya.

Giessen, L., \& Krott, M. (2009). Forestry Joining Integrated Programmes? A question of willingness, ability and opportunities. Allgemeine Forst Und Jagdzeitung, 180(5/6), 94-100.

Gilang Fauzi. (2014). Zulkifli Hasan Dituding Serahkan Izin Langsung ke Riau.

Gubernur Riau. (2017). Rancangan Peraturan Daerah Provinsi Riau tentang Rencana Tata Ruang Wilayah Provinsi Riau 2017-2037.

Higgot, R. A., Underhill, G. R. D., \& Bieler, A. (2000). Non-state actors and authority in the global system. Routledge. doi:10.4324/9780203279380.

Horton, J., Macve, R., \& Struyven, G. (2004). Qualitative research: Experiences in using semi-structured interviews. In The Real Life Guide to Accounting Research (pp. 339-357). New York: Elsevier Ltd. doi:10.1016/B978-008043972-3/50022-0.

Hsieh, H.-F., \& Shannon, S. E. (2005). Three approaches to qualitative content analysis. Qualitative Health Research, 15(9), 1277-1288. doi:10.1177/1049732305276687.

Hubo, C., \& Krott, M. (2013). Conflict camouflaging in public administration - A case study in nature conservation policy in Lower Saxony. Forest Policy and Economics, 33, 63-70. doi:10.1016/j.forpol.2012.10.008.

Hudalah, D., \& Woltjer, J. (2007). Spatial planning system in transitional Indonesia. International Planning Studies, 12(3), 291-303. doi:10.1080/13563470701640176.

Hukrim. (2017). Jikalahari Desak DPRD Riau Hentikan Pembahasan Ranperda RTRWP Riau 2016-2035.

Kartodihardjo, H., \& Supriono, A. (2000). The Impact of sectoral development on natural forest conversion and degradation: The case of timber and tree crop plantations in Indonesia (CIFOR Occasional Paper No.26(E)). Bogor, Indonesia. doi:10.17528/cifor/000628.

Kartodiharjo, H. (2010). Upaya penyelesaian konflik tata ruang terkait dengan Kawasan Hutan Negara. Jakarta: Sub Direktorat Penataan Ruang Kawasan Hutan Wilayah I.

Kementerian ATR/BPN. (2016). Instrumen penataan ruang yang mendukung pembangunan. Jakarta.

Krippendorff, K. (1989). Content analysis. In E. Barnouw, G. Gerbner, W. Schramm, T. L. Worth, \& L. Gross (Eds.), International Encyclopedia of Communication (pp. 403-407). New York: Oxford University Press. 
Retrieved from http://repository.upenn.edu/asc_papers/226.

Krott, M. (2005). Forest policy analysis. Netherlands: Springer. doi:10.1007/1-4020-3485-7.

Krott, M., Bader, A., Schusser, C., Devkota, R., Maryudi, A., Giessen, L., \& Aurenhammer, H. (2014). Actorcentred power: The driving force in decentralised community based forest governance. Forest Policy and Economics, 49, 34-42. doi:10.1016/j.forpol.2013.04.012.

Lele, G. (2016). Pengelolaan konflik dalam kebijakan publik. In A. Subarsosno (Ed.), Kebijakan Publik dan Pemerintahan Kolaboratif, Isu-Isu Kontemporer (I). Yogyakarta: Gava Media.

Longhurst, R. (2003). Semi-structured interviews and focus groups. In N. Clifford \& G. Valentine (Eds.), Key Methods in Geography (pp. 117-129). London: Sage Publications.

Louise Barriball, K., \& While, A. (1994). Collecting data using a semi-structured interview: a discussion paper. Journal of Advanced Nursing, 19, 328-335. doi:10.1111/j.1365-2648.1994.tb01088.x.

Lynch, O. J. (1999). Promoting legal recognition of community-based property rights, including the commons: some theoretical considerations. In Paper presented at a Symposium of the International Association for the Study of Common Property and the Workshop in Political Theory and Policy Analysis. Bloomington, Indiana.

Mahkamah Konstitusi. (2011). Putusan MK Nomor 45/PUU-IX/2011. Jakarta.

Maryudi, A. (2015). The political economy of forest land-use, the timber sector, and forest certification. In The Context of Natural Forest Management and FSC Certification in Indonesia (pp. 9-34). Bogor, Indonesia: Center for International Forestry Research.

McCarthy, J. (2000). The changing regime: Forest property and reformasi in Indonesia. Development and Change, 31(1), 91-129. doi:10.1111/1467-7660.00148.

Myers, R., \& Ardiansyah, F. (2014). Siapa yang memegang kekuasaan dalam tata guna lahan? Dampaknya bagi $R E D D+$ di Indonesia. Bogor, Indonesia. doi:10.17528/cifor/005517.

Niskanen, W. A. (1971). Bureaucracy and representative government. New Brunswick, USA and London UK: Aldine Transaction.

Ombudsman Republik Indonesia. (2016). Rekomendasi Ombudsman RI Nomor : 0002/REK/0361.2015/PBP41/II/2016.

Opdenakker, R. (2006). Advantages and disadvantages of four interview techniques in qualitative research. Forum Qualitative Sozialforschung/Forum: Qualitative Social Research, 7(4), Art. 11. Retrieved from http://nbn-resolving.de/urn:nbn:de:0114-fqs0604118.

Peters, B. G. (2001). The politics of bureaucracy. London and New York: Routledge, Taylor \& Francis Group.

Prabowo, D., Maryudi, A., Senawi, S., \& Imron, M. A. (2017). Conversion of forests into oil palm plantations in West Kalimantan, Indonesia: insights from actors' power and its dynamics. Forest Policy and Economics, 78, 32-39. doi:10.1016/j.forpol.2017.01.004.

Resosudarmo, B. P., Nawir, A. A., Resosudarmo, I. A. P., \& Subiman, N. (2012). Forest land use dynamics in Indonesia (Working Papers in Trade and Development no. 2012/01). Australia. Retrieved from https://www.cifor.org/library/3785/.

Riau Pos. (2014). Ada HGU-HPHTI di balik RTRW. Retrieved October 17, 2017, from http://riaupos.co/2073spesial-ada-hgu-hphti-di-balik-rtrw.html\#.XFoyQzAzbIV.

Ribot, J. C., \& Peluso, N. L. (2003). A theory of access. Rural Sociology, 68(2), 153-181. doi:10.1111/j.15490831.2003.tb00133.x.

Riyan Novitra. (2016). Suap Alih Fungsi Lahan, KPK Periksa 9 Pejabat Riau.

Robertson-Snape, F. (1999). Corruption, collusion and nepotism in Indonesia. Third World Quarterly, 20(3), 589-602. doi:10.1080/01436599913703.

Rukmana, D. (2015). The change and transformation of Indonesian spatial planning after Suharto's new order regime: The case of the Jakarta Metropolitan Area. International Planning Studies, 20(4), 350-370. doi:10.1080/13563475.2015.1008723.

Sahide, M. A. ., Maryudi, A., \& Giessen, L. (2016). Decentralisation policy as recentralisation strategy: forest management units and community forestry in Indonesia. The International Forestry Review, 18(1), 7895.

Sahide, M. A. K., \& Giessen, L. (2015). The fragmented land use administration in Indonesia - Analysing 


\section{Kontestasi Aktor dalam Proses Revisi Rencana Tata Ruang Provinsi (RTRWP) di Indonesia ...}

bureaucratic responsibilities influencing tropical rainforest transformation systems. Land Use Policy, 43, 96-110. doi:10.1016/j.landusepol.2014.11.005.

Santoso, H. (2003). Forest area rationalization in Indonesia: A study on the forest resource condition and policy reform. Bogor, Indonesia: ICRAFT.

Schusser, C., Krott, M., Devkota, R., \& Maryudi, A. (2013). Sequence design of quantitative and qualitative surveys for increasing efficiency in forest policy research. Allgemeine Forst Und Jagdzeitung, 183(3), 7583.

Setiawan, E. N., Maryudi, A., Purwanto, R. H., \& Lele, G. (2016). Opposing interests in the legalization of nonprocedural forest conversion to oil palm in Central Kalimantan,Indonesia. Land Use Policy, 58, 472-481. doi:10.1016/j.landusepol.2016.08.003.

Setiawan, E. N., Maryudi, A., Purwanto, R. H., \& Lele, G. (2017). Konflik tata ruang kehutanan dengan tata ruang wilayah (studi kasus penggunaan kawasan hutan tidak prosedural untuk perkebunan sawit Provinsi Kalimantan Tengah). Bhumi: Jurnal Agraria Dan Pertanahan, 3(1), 51-66. Retrieved from http://jurnalbhumi.stpn.ac.id/index.php/JB/article/view/226.

Sève, J. (1999). A review of forestry sector policy issues in Indonesia (Technical Report No. OUT-PCE-I-80696-00002-00). Jakarta.

Sinabutar, P. (2015). Penataan tenurial dan peran para pihak dalam mewujudkan legalitas dan legitimasi Kawasan Hutan Negara. Institut Pertanian Bogor.

Situmorang, A. W., \& Kartodiharjo, H. (2016). Kajian tata kelola hutan 2015. UNDP Indonesia.

Steni, B. (2016). Membedah UU pemerintahan daerah yang baru. Retrieved from https://earthinnovation.org/wp-content/uploads/2014/09/INOBU-Report-Membedah-UUPemerintahan-Daerah-yang-Baru.pdf.

Sugiyono, S. (2016). Metode penelitian kuantitatif, kualitatif, dan kombinasi (Mixed Methods). (Sutopo, Ed.) (8th ed.). Bandung: CV Alfabeta.

Susanti, A., \& Maryudi, A. (2016). Development narratives, notions of forest crisis, and boom of oil palm plantations in Indonesia. Forest Policy and Economics, 73, 130-139. doi:10.1016/j.forpol.2016.09.009.

Syahadat, E., \& Subarudi, S. (2012). Permasalahan penataan ruang kawasan hutan dalam rangka revisi rencana tata ruang wilayah provinsi. Jurnal Analisis Kebijakan Kehutanan, 9(2), 131-143. doi:10.0.81.150/jakk.2012.9.2.131-143.

Tim Terpadu. (2012). Laporan hasil kajian tim terpadu usulan perubahan kawasan hutan dalam pemaduserasian TGHK dengan RTRWP Riau. Jakarta.

Wibowo, A., \& Giessen, L. (2015). Absolute and relative power gains among state agencies in forest-related land use politics: The ministry of forestry and its competitors in the REDD + programme and the one map policy in Indonesia. Land Use Policy, 49, 131-141. doi:10.1016/j.landusepol.2015.07.018. 